\title{
2. Soledumbre, transmutación fantasmática en el taller del historiador
}

\author{
"Estoy solo, sola. Dice él o dice ella. Estoy solo, sola. \\ Escuchemos esta frase completamente sola, \\ seguida por un silencio inapelable o por un punto final" (Derrida, 2011, p. 21).
}

"El super-hombre, el caminante solitario, el esquivo [...]" (Nietzsche, 2006b, p. 47).

"Si no consigo inventar el artificio de los alquimistas para transformar este fango en oro, estoy perdido" (Nietzsche, 2010, p. 306).

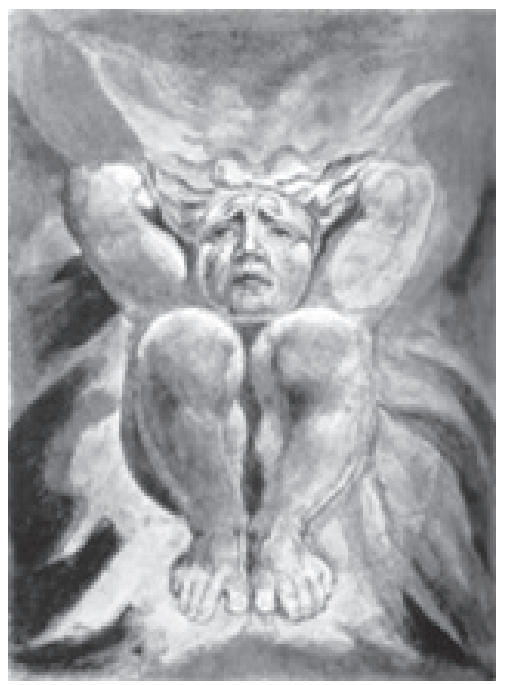

Martirio de Los, en El libro de Urizen, W. Blake, Lambeth, 1794 angustia, soledad y transmutación. Fuente: Blake (2013, p. 342). 
From the depths of dark solitude, From

The eternal abode in my holiness,

Hidden, set apart, in my stern counsels,

Reserv'd for the days of futurity. ${ }^{26}$

The first book of Urizen II, 4 (Blake, 1998, p. 176)

Luego de visitar, asediar y dejarse asediar por la compañía amenazante, pero también por la potencia tremebunda de las bestias y dragones que constituían el motivo del anterior capítulo; agobiados al mismo tiempo por la pregunta de si esos monstruos no representan acaso la soledad misma; la extrema soledad de Nietzsche escribiendo el Zaratustra, el soberano Zaratustra, La bestia y el soberano que es Zaratustra, el eterno retorno y Zaratustra, dragones y héroes en franca lid, en magistral liza, en batalla ciclópea e indecidible; también el Super hombre y su dragón tenebroso, se sigue hilando este recorrido de alejamientos, el de Nietzsche mismo por esta época, tal como expresa en una carta desde Génova dirigida a Heinrich Köselitz el 27 de abril de 1883: "Por lo demás, me he propuesto adoptar este punto de vista: cuanto más se olviden de mí, mucho mejor será para mi hijo, que se llama Zaratustra. En consecuencia, me espera una vida aún más oculta que la pasada" (Nietzsche, 2010, p. 351).

\subsection{SOLEDUMBRE}

Al observarla figura de $\operatorname{Los}^{27}$, tomada del Libro de Urizen de William Blake (17571827) que abre este apartado, se aprecia un ser flamígero, como se sostiene en Alquimia y Mística, el Museo Hermético precisamente al respecto de esta imagen: "En la figura de Los, el profeta de la imaginación, Blake ha incluido la concepción que tenía Paracelso del "volcán interior" (Archeus), al que llama "artífice y artesano de todas las cosas". Es el fuego secreto que en el interior de la Naturaleza transforma el espíritu divino en materia" (Roob, 1997, p. 230).

Consumido quizá en el ardor de un apartamiento transmutante, en una postura fetal, arrollado sobre sí mismo, pero también en una rara y acuclillante crucifixión, este ser aparece como encajonado en una superficie rocosa: "Sendivogius, discípulo de Paracelso, lo llama "sol central, corazón del mundo" ("Los" es anagrama de Sol). El acto satánico de Urizen, consistente en separarse de la eternidad en la que estaba,

\footnotetext{
26 "De las profundidades de la soledad oscura,

De la morada eterna, en mi escondida

Beatitud, retirado en mis austeras meditaciones

Guardadas para días del futuro".

El primer libro de Urizen, II, 4 (Blake, 1998, p. 177).

27 Cabe anotar que "Los" es el vocablo alemán que en la traducción de Así habló Zaratustra, Andrés Sánchez Pascual vierte por "destino".
} 
lo arroja al vacío, al que debe darle forma y contorno" (Roob, 1997, p. 230); la paleta de rojos contribuye a crear una atmósfera incandescente, infernal acaso, casi como sufriendo un castigo indeterminado, del que se sugiere su causa en la soledad y el aislamiento, suerte de robusto y enigmático Prometeo.

De este apesadumbrado apenas se especula la naturaleza de su compunción, el abatimiento expresado, su rostro demudado de angustia y de sufrimiento, como quería Nietzsche de sí mismo para decantar su obra, extraer de sí y de su aislamiento el elíxir alquímico; si es que la quintaesencia o elíxir no era la soledad misma, como un fármakon terriblemente venenoso, pero balsámico en sus posibilidades, como escribe a Franz Overbeck: "me he repetido cien veces que el remedio sustancial para mi salud, en los últimos tres años, ha sido el abstenerme de cualquier contacto humano" (Nietzsche, 2010, pp. 340-341).

Pero no hay que olvidar que esa "cura" o "desintoxicación" de la compañía debilitante de sus semejantes también tiene efectos secundarios: "en la soledad en la que vivo, aquí o en la Engadina, estoy enfermo continuamente" (Nietzsche, 2010, p. 506), dice en una comunicación dirigida a su madre y su hermana el 26 de noviembre de 1884; enfermo de soledad y curándose a través de ella misma, suministrándosela en dosis incalculables, esa ambivalencia consustancial e ineliminable de la locución griega pharmakon puesta aquí a jugar en sus más ominosas pero fecundas y lúdicas posibilidades.

Urizen es el nombre del personaje que expulsa a Los, según la cita del Museo Hermético, en la saga cosmo-gónica de William Blake sería un parónimo onomatopoético de your reason o de horizon, una prosopoiesis o personificación de la facultad intelectual del ser humano una vez se ha separado de las esencias inmutables y la eternidad. Casi como si esta imagen significara el pasmo doloroso de la caída, de la materialización de una potencia nouménica, ígnea o incluso arquetípica. El paso angustioso de lo eterno a la cadena causal de la cronología lineal, el dolor fascinado de la encarnación en un cuerpo sometido a la degradación y la finitud; también debido al proceso de individuación consustancial a esta mutación, determinado a sentirse inmensamente solo.

Viendo el rostro de Los se recuerda la afirmación del final del apartado 13 del "Hombre Superior", volviendo a esa escena: "En la soledad crece lo que uno ha llevado a ella, también el animal interior. Por eso resulta desaconsejable para muchos la soledad" (Nietzsche, 2006, p. 396), anticipando lo que "crecerá", "germinará" o "florecerá" en la soledad como campo ontológico de experimentación, anticipando lo que nunca será anticipable, entonces; un apartarse soberano, auto-decidido y consciente, pero siempre dudoso y ambiguo en alguna dimensión de su práctica desoladora, ese dejar atrás "las moscas en el mercado".

En ese apartado de la primera parte de Así habló Zaratustra, la exhortación es clarísima: “¡Huye, amigo mío, a tu soledad! Ensordecido te veo por el ruido de los grandes hombres, y acribillado por los aguijones de los pequeños, [...] Donde acaba 
la soledad, allí comienza el mercado; y donde comienza el mercado, allí comienzan también el ruido de los grandes comediantes y el zumbido de las moscas venenosas" (Nietzsche, 2006, p. 90); para acabar repitiendo: "Huye, amigo mío, a tu soledad, y allí donde sopla un viento áspero, fuerte. No es tu destino el ser espantamoscas" (Nietzsche, 2006, p. 93).

También el inicio del episodio con la "chusma" aborda este tema, ya en la segunda parte: "la vida es un manantial de placer; pero donde la chusma va a beber con los demás, allí todos los pozos quedan envenenados” (Nietzsche, 2006, p. 151). El separarse de esa impureza es expresado por Zaratustra en estos términos: "Pues ésta es nuestra altura y nuestra patria: en un lugar demasiado puro y abrupto habitamos nosotros aquí para todos los impuros y para su sed" (Nietzsche, 2006, p. 153).

Se trata, en suma, de alejarse de esa chusma, de las impertinentes e infectas moscas del mercado, así como saber "pasar de largo" ante el ruido y la podredumbre de la "gran ciudad" (Nietzsche, 2006, pp. 252-255), incluso del "mono de Zaratustra" que le advierte sobre esas miserias. Se trata de una suerte de retiro, la anakhoresis de la que también hablaba Foucault en la antigüedad grecolatina como una práctica de sí y un ejercicio de existencia, aunque con un plexo de significados más amplio:

Otra técnica, otro procedimiento que compete a estas tecnologías del yo: la técnica de la retirada, para la cual hay una palabra que, como saben, va a tener una suerte considerable en toda la espiritualidad occidental: la palabra anakhoresis (la anacoresis). La retirada, entendida en estas técnicas arcaicas de sí, es una manera determinada de apartarse, de ausentarse - pero de ausentarse in situ - del mundo dentro del cual estamos situados: en cierto modo, cortar el contacto con el mundo exterior. (Foucault, 2004, p. 60) 28 $^{28}$

Este retiro anacorético, incluso si es in situ como veremos en el quinto momento escogido del recorrido de la soledad de Zaratustra, está cargado de augurios y remembranzas en Así habló Zaratustra:

¡Oh soledad! ¡Tú patria mía, soledad! ¡Ha sido demasiado el tiempo que he vivido de modo salvaje en salvajes países extraños como para que no retorne a ti con lágrimas en los ojos!", dice en la tercera parte a propósito del "retorno a casa ", a la soledad como el más dulce y anhelado de los hogares: "Una cosa es abandono, y otra distinta, soledad: ¡Esto lo has aprendido ahora! Y que entre los hombres serás tú siempre salvaje y extraño. (Nietzsche, 2006, p. 261)

La idea de que solo a partir de la soledad, únicamente acompañados por su posibilidad, es posible deshacerse de los prejuicios de la vida en común, curarse de la mediocridad del medioambiente simbólico dominante, del enrarecido clima afectivo

28 En el tercer capítulo intentaremos hacer una relación más estrecha entre los trabajos de Foucault -en particular sus últimos seminarios en el Collège de France (El gobierno de sí y de los Otros I y II) y la obra de Nietzsche, guiados por la noción de parrhesía. 
de tantas personas conviviendo, co-inspirando una cierta forma de ver el mundo, saturando el entorno con un común aliento ${ }^{29}$, una empobrecedora perspectiva homogenizante: como había dicho Nietzsche de la cura o remedio "sustancial" para su salud al referirse a la ausencia total de contacto humano en la carta que citábamos. $\mathrm{Y}$ todo para dejar de respirar esa atmósfera perniciosa, cargada de valoraciones determinadas por la moralina cristiana esparcida como nube tóxica sobre la Europa de fin de siglo, un clima del que no dejará de quejarse Nietzsche y del que ya tendremos oportunidad, en el tercer capítulo no tanto de mirar o analizar, sino tal vez de aspirar con más detalle.

Esa asfixia en el entorno cultural e intelectual de su época, ha obligado al autor del Zaratustra a huir de la aglomeración, a mostrarse intolerante con la reunión masiva de gente. Como una característica de este pensador, sus biógrafos no se han cansado de señalar este temperamento huraño y misántropo, sobre el cual ha dicho él mismo en una carta a Franz Overbeck el 22 de diciembre de 1884: "Prefiero mil veces mi vida de absoluto retiro, a la compañía de exaltados mediocres” (Nietzsche, 2010, p. 514).

El asunto no es la búsqueda de compañía como tal, en ese gregarismo socializante que exigiría a los hombres juntarse indiscriminadamente, sin atender a las singularidades o pasando por alto las evidentes diferencias, paroxismo de fraternidad universal para el que "todos los hombres son hermanos".

Se ve con nitidez el aristocratismo de Nietzsche como un rasgo de distinción, muy lejos de querer tener un "millón de amigos" o algo de ese estilo, la frase en que se renuncia a la cercanía de "exaltados mediocres" es un tributo a la soledad, un homenaje a la propia estima, a la estética del creador que no quiere confundirse con el "rebaño", con la masa de individuos acríticos y predecibles que pululan a su alrededor, ese "absoluto retiro" que no hace concesiones apremiado por la insoportable soledad, ni agobiado por la falta de alguien con quien compartir su tiempo se entrega al contacto o la amistad de cualquiera.

Esta posición que parece tan arrogante, misántropa en extremo o por lo menos indelicada, en concreto, tiene que ver con el desencuentro - en invierno de 1884de Nietzsche con un seguidor suyo llamado Paul Lansky, que se ofrecía a hacerle compañía y además conocía su obra y había escrito algún artículo sobre ella en un periódico húngaro (cf. Nietzsche, 2010, p. 514).

29 Resuena aquí esta frase del jefe indio norteamericano Noah Sealth, o jefe Seattle, quien en el famoso "Manifiesto Ambiental" de 1854, respondiendo a la propuesta del entonces presidente Franklin Pierce de comprar las tierras indígenas, en un apartado dice: "No entendemos por qué se exterminan los búfalos, se doman los caballos salvajes, se saturan los rincones secretos de los bosques con el aliento de tantos hombres y se atiborra el paisaje con de las exuberantes colinas con cables parlantes", recalcamos la frase se saturan los rincones secretos de los bosques con el aliento de tantos hombres, como si la respiración de una multitud perturbara el equilibrio del ecosistema tanto biológico como espiritual de la tierra, recargando la atmósfera innecesariamente, sobre todo los sitios sagrados para las comunidades indígenas. Si esto fue dicho a finales del siglo XIX, imaginamos lo que podría pensar el jefe Seattle de la densidad poblacional de las grandes ciudades hoy en día y la explosión demográfica que azota el planeta, el insostenible hábitat que ha configurado el hombre en la actualidad. 
Se entiende aquí en toda su complejidad y altivez la búsqueda de discípulos de Nietzsche como algo radicalmente distinto del afán de reconocimiento, gloria o renombre de acuerdo a los criterios usuales para otorgarlos, en un borrador que data de finales de 1884, dice: "Querido señor Levi. Quién sabe si se acordará usted aún de mí. Pues soy un ermitaño, y si yo mismo he olvidado a medio mundo, con razón al menos tres cuartas partes del mundo (o más) se habrá olvidado de mí" (Nietzsche, 2010, p. 515).

Sin embargo, vemos emerger cierta preocupación por su anonimato en otra carta a su hermana en noviembre de ese año, en la que se refiere muy negativamente a la labor de su editor Schmeitzner, y con la advertencia de que esto debía quedar "privatissime entre nosotros", allí dice: "desde hace tiempo mi nombre ya no es citado en ninguna revista científica, tanto nacional como extranjera" (Nietzsche, 2010, p. 501).

En este horizonte abierto por Nietzsche para dedicarse completamente a la escritura, a la exploración de su animal o animales interiores, en el tono de lo anotado en el numeral quinto del anterior capítulo, es posible ahora problematizar la distinción habitual entre adentro y afuera (como ocurre con la expresión del sicoanálisis lacaniano "éxtimo": exterior e íntimo a la vez), conjugando la exterioridad de una tarea monstruosa, la transmutación de todos los valores, así como la anunciación del eterno retorno como doctrina con el peso de cargar con esas intuiciones y perspectivas mayúsculas.

Sin saber si esos duendes, bestias o incluso fantasmas se hallan dentro o fuera de la tenue membrana identitaria que llamamos "Friedrich Nietzsche" o "Zaratustra", dentro o fuera de esa soledad soberanamente elegida, como ocurre con la figura de Los flamígero, pero también abandonado de sí, dejado por mano propia y ajena de la compañía de los hombres. Se prosigue este recorrido anunciando también el sentido que Jacques Derrida le va a dar a la segunda parte del seminario La bestia y el soberano:

Ya presienten ustedes que de lo que se va a tratar aquí es de isla, de insularidad, de aislamiento, de soledumbre (será, si quieren, un seminario sobre la soledad: ¿qué quiere decir "ser/estar solo" o "soy/estoy solo"?) Pero, puesto que ser/estar solo quiere decir también ser singular, único, excepcional, aparte, estar separado, habrá que decir asimismo que, aunque las bestias no están solas, un soberano siempre es/está solo (es a la vez su poder absoluto y su vulnerabilidad o su inconsistencia infinita). El soberano es/está solo en cuanto que es único, indivisible y excepcional. (Derrida, 2011, p. 28) 


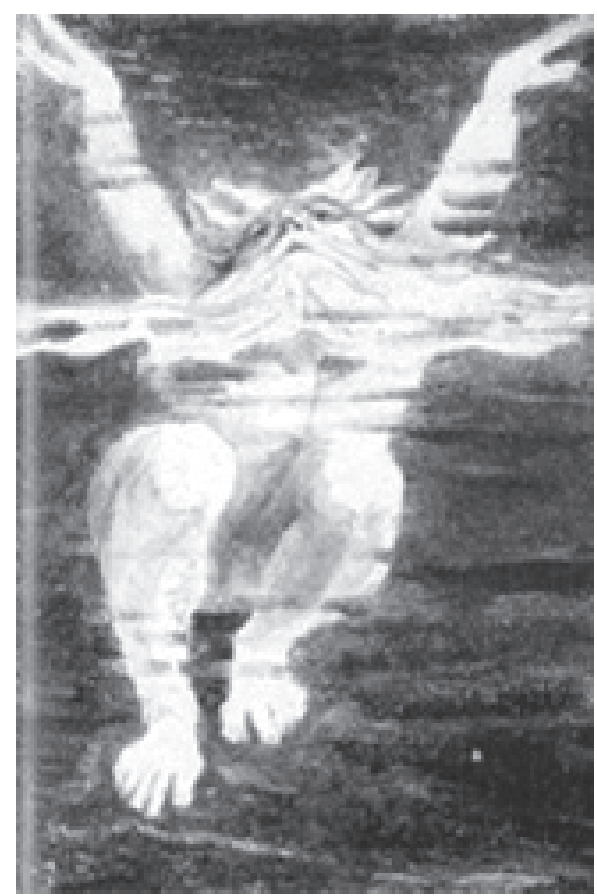

El rey Urizen se sumerge en el "fluido sulfuroso de sus sueños"

W. Blake, El libro de Urizen, Lambeth, 1794. Fuente: Blake (2013, p. 305).

Enraged \& stifled with torment,

He threw his right Arm to the north,

His left Arm to the south

Shooting out in anguish deep,

And his feet stamp'd the nether Abyss

In trembling \& howling \& dismay ${ }^{30}$

The first book of Urizen IV [a], 12 (Blake, 1998, p. 186)

Sintiendo la compañía de la terrible soledad del rey Urizen, como sumergido en el fluido sulfuroso de sus propios, singulares y muy particulares sueños, dando brazadas y patadas de monarca ahogado, se nota que a diferencia de la primera imagen en esta la paleta ya no está marcada por los rojos y los matices son mucho menos vivaces e incandescentes.

30 "Furioso, ahogado en su tormento,

Lanzó su Brazo derecho hacia el norte,

Y hacia el sur su Brazo izquierdo,

Con angustia profunda,

Y sus pies hollaron los Abismos,

Tembloroso, ululante, despavorido".

El primer libro de Urizen, IV [a], 12 (Blake, 1998, p. 187). 
El rey Urizen está solo, quizá injustamente solo, padeciendo la excepcionalidad de su condición soberana, como dice Derrida en la cita anterior, sumergido en ese ámbito "sulfuroso" parece extasiado y agónico a un tiempo. Su postura recuerda la de Los, solo que los brazos extendidos indican algo radicalmente distinto a la forzada flexión de la primera figura.

Como queriendo bucear ese inhóspito mar interno, interno externamente o exteriormente intrínseco, onírico o incluso amniótico, deseando salir de allí o remontarse a otra altura, hondura o posibilidad de asumir un cuerpo distinto, brutal sentimiento que nos pone en contacto con ese desarraigo al que alude Derrida comentando el seminario Die Grundbegriffe der Metaphysik. Welt - Endlichkeit - Einsamkeit ("Los conceptos fundamentales de la metafísica: Mundo, Finitud y Soledad”) de Martín Heidegger, dictado en Friburgo entre 1929 y 1930, allí se sostiene:

¿Qué es la soledumbre, el aislamiento o la soledad (Vereinzelung, Einsamkeit)? Esa Vereinzelung (esa soledumbre, ese aislamiento, esa insularidad) no es la rigidez de un pequeño yo que se pavonea ante lo que considera el mundo. Más bien es la soledumbre, el quedarse solo, el soportar la soledad (Vereinsamung) mediante la cual el hombre logra por primera vez aproximarse a lo esencial de todas las cosas, aproximarse al mundo [...]. Soledad del hombre, cuestión del hombre como único ser vivo capaz de estar solo y de acercarse al mundo como tal. (Derrida, 2011, p. 55)

Esa soledad como condición para un "aproximarse a lo esencial de todas las cosas" parece una consigna de Nietzsche, quien recurriría a ella motivado no solo por el fastidio mayor que despiertan en él sus congéneres, ese desencanto de fondo con el tipo de personas que componían su medio tanto cotidiano como su entorno "intelectual", desde sus más inmediatos vecinos hasta figuras destacadas de la filología en la universidad de Basilea.

Para no hablar del mismo Richard Wagner y otros grandes personajes de la escena artística y filosófica de su época, sino que la huida a sí mismo estaría determinada por una suerte de ascética de sí en la que Nietzsche espera decantar sus propias ideas, como un crisol para depurar su escritura, de la que nacerá su obra como quintaesencia.

Ahora bien, ¿por qué la soledad permite lograr esto?, ¿cuál es el mecanismo o la magia que lograría esta transmutación?, si no se trata de un "pavonearse" ante el mundo o una mera pose para aparentar excentricidad, simular ser interesante o profundo o lo que sea, ¿qué es lo que ocurre cuando se está solo?

El "soportar" del que habla la anterior cita nos pone sobre una pista valiosa: no se trataría de un mero goce, de un disfrute de este estado de soledumbre, aunque tenemos muchas razones para suponer esto en el caso del autor del Zaratustra, claro, pero por el tono de su correspondencia podemos figurar algo de lo que también estaba en juego en una apuesta existencial semejante: "Ahora la soledad casi me provoca terror: pero ya he aprendido a apretar los dientes" (Nietzsche, 2010, p. 363), dice a su 
hermana Elisabeth Nietzsche en una postal del 15 de junio de 1883. Pero es en una carta un poco anterior (28 de mayo de 1883) dirigida a Marie Baumgartner, y que citamos más en extenso, donde encontramos una importante clave interpretativa:

A esto va ligada una decisión mía, que desde hace años no estoy seguro de tomar o abandonar, y para la que finalmente — iahora! - me siento maduro y bastante fuerte: la decisión de "desaparecer" por algunos años.

Aunque quizás, estimada amiga, ¿piensa usted que ya "he desaparecido" bastante? ¡Y su última carta, de una bondad infinita, parece expresar el deseo de que más bien yo "emerja de nuevo" de las oscuras aguas del aislamiento!

Consulte acerca de esto también a mi hijo Zaratustra: y si fuese necesario disculparme por alguna "culpa", ¡le tocará a él disculparme!

Quiero vivir una vida dura como nadie más: sometido a esta presión, y no de otra manera, conseguiré sentirme con buena consciencia por el hecho de poseer aquello que pocos seres humanos tienen o han tenido: ALAS -Por decirlo con una metáfora.

¡No se enfade conmigo, aun cuando haya "desaparecido" y "volado lejos"!

Sinceramente su amigo. (Nietzsche, 2010, p. 362)

Resalta de inmediato la gran dureza y peso excesivo de esta decisión de apartarse, precio hiperbólico que debe pagar quien pretende una recompensa también hiperbólica: "tener alas"; como en el interior de una crisálida enorme, la oruga Nietzsche anhela la fase final de su dolorosísima metamorfosis, más dolorosa cuando sabe que el sufrimiento no es solo el suyo, sino el de las personas más próximas a él, todos aquellos que deben padecer su ausencia, y más si, como dice esta carta, sus más allegados desean que "emerja de nuevo". La forma de disculparse o excusarse por esto no es menos excepcional, se invoca a su "hijo" Zaratustra.

La interpolación del personaje literario como alguien capaz de interactuar extraliterariamente, mediando en este tipo de temas, ayudando a resolver conflictos no emanados solo de las ideas presentes en el libro como tal, sino de situaciones derivadas de las circunstancias en que fue escrito.

Pedir que le "consulten" a su "hijo" nos permite entender la gravedad de la tarea a que se había entregado y a la que pensaba consagrarse de un modo aún más radical en el futuro. Su obra es la justificación de su vida, más allá de cualquier otra meta u objetivo de "felicidad" o "confort" propio de un horizonte de expectativas ligado a los significados culturalmente disponibles en su momento, como tener una familia, amasar una fortuna o permitirse el tipo de comodidades que el mundo burgués podía ofrecerle, o incluso exigir a alguien en su posición. Negándose valerosamente a todo ello, solo a través de sus libros podrían las personas que lo conocieron llegar a disculparlo, seguro de alcanzar su objetivo; en la última línea incluso anticipa su "irse" y "volar lejos". 
Esa trascendencia por la escritura es justo el motivo de este cuestionamiento, porque si así pensaba Nietzsche en el momento de configuración de Así habló Zaratustra, ¿qué podemos pensar de una lectura actual de este texto con más de un siglo de distancia de la fecha de su primera publicación?, ¿cómo valorar ese sacrificio de sí realizado por un autor absolutamente embebido en lo más sombrío y magnífico de su tarea?, ¿cómo agradecer, disculpar o aplaudir este gesto grandioso?, ¿ este exceso de narcisismo, autosuficiencia o renunciación?, ¿a quién retribuirle tantas y tantas privaciones si no es a ese fantasma que ya Nietzsche presentía y respiraba en vida y que era y no era él mismo?

También es relevante el uso de la palabra "desaparecer" en la carta que ahora leemos, pues refuerza la idea de un tipo de desaparición que sobre-expone al autor a destacarse póstumamente, pero ya se hablará de ello en el último apartado de este capítulo. Por ahora se finalizará con unas anotaciones sobre el carácter y las implicaciones de esta decisión de estar solo, abrigados con el calor que emana de esta tercera imagen de William Blake, la del rey Urizen al parecer con grilletes, en postura de trance paroxístico y meditado, retornando a la imagen ígnea de combustión de sí mismo, como en el proceso alquímico de obtención de la piedra filosofal o lapitas philosophorum:

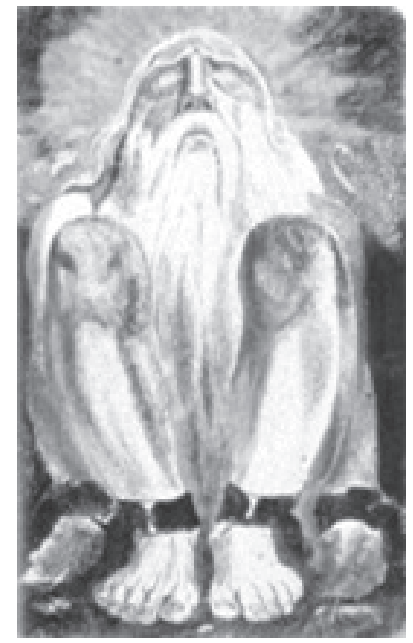

El Rey Urizen encadenado y llameante. Fuente: Blake (2013, p. 326).

Age on ages he lay, clos'd, unknown,

Brooding shut in the deep; all avoid

The petrific, abominable chaos ${ }^{31}$

The first book of Urizen I, 5 (Blake, 1998, p. 174).

31 "Edades tras edades él yació, misterioso, desconocido,

Meditando, prisionero del abismo; todos eluden

El caos petrífico y abominable".

El primer libro de Urizen I, 5 (Blake, 1998, p. 175). 
Sobre esta imagen nos dice el tratado de Alquimia y Mística: "Urizen, señor del sol material, gozaba antes de eterna juventud y encarnaba la 'confianza y la certidumbre', pero, después de retirarse de la eternidad, encarna la duda destructiva y la razón calculadora" (Roob, 1997, p. 231), llama la atención la expresión "retiro de la eternidad" como si en esa esfera gozara de autocompletud y no sufriera la incertidumbre y la duda de haberse "retirado" de ella, quedando a merced de los procesos cognitivos de la racionalidad científica, o por lo menos de la racionalidad instrumental, "calculadora".

Como si Urizen en este trance, solo, desprendido de la eternidad, separado de sus atributos divinos, estuviera encadenado por el infatigable fluir del pensamiento, de la omnipresente duda propia de un modo de pensar ligado al Logos como ratio, como cálculo incesante y apesadumbrante sobre las cosas. Pero ¿de qué manera ocurrió la separación de estos principios?: "Por opuestos que sean Urizen y Los 'en el mundo uterino', en la eternidad eran gemelos univitelinos. Bajo tremendos dolores, Urizen llegó a desprenderse de Los" (Roob, 1997, p. 231). Ese tremendo esfuerzo de Urizen por desprenderse de Los, como aislándose y apartándose, depurándose y contaminándose de materia, pareciera provenir de una voluntad soberana, segura de sí, que comprende las consecuencias de este supremo gesto y lo celebra como parte de una actitud guerrera y sumamente valiente y autoasumida.

Se trata de un gesto que incluso lo distingue de muchos otros que no se atreverían a tomar una decisión de tal calibre, con tales pasmosas e inabarcables consecuencias: vivir el aislamiento y el retiro más excepcionales e irreversibles. Esto si es que acaso la consciencia de sí no implica siempre una instancia soberana, excepcional, retirada del resto de los hombres por efecto de su resplandeciente majestad, un retiro exigido para constituirse como rey sobre las bestias, como cabeza sobre todo lo demás. Sobre esto Jacques Derrida, esta vez comentando "Las ensoñaciones de un paseante solitario" de J. J. Rousseau (a quien tanto vapulea Nietzsche en los fragmentos póstumos del otoño de 1887, por el sentido que da a la consigna "retorno a la naturaleza"), dice:

No solamente yo estoy solo, solitario, etc., sino que yo soy el único (por ende, el señero, el irremplazable, el elegido, casi) a quien esa soledad que amo naturalmente, solitario como soy por naturaleza, le haya sido también impuesta como una ley; y, aunque yo no pueda creer que soy el único que posee ese gusto innato, natural, por la soledad, hasta ahora no he encontrado a nadie más con quien compartirla.

Por consiguiente, estoy solo, amo naturalmente la soledad y soy el único que la tiene tanto por naturaleza como por ley. Esta soledad es pues tan esencial, tan profunda, tan abisal que me define en mi ipseidad absoluta o en el destino único de mi ipseidad. Soy el único, soy el único que está tan solo, y el único que ama naturalmente estar solo. (Derrida, 2011, p. 97)

A medio camino entre el amor fati y la creación del propio destino, el soberano ama lo que él mismo se impone, la soledad a que se ha visto obligado también, una 
condición de excepcionalidad que sufre y goza debido a su fortuna descomunal, como la meta hiperbólica que se ha trazado Nietzsche: convertirse en un ser alígero, trascender la visión prosaica y adocenada de sus semejantes, transformarse en el soberano de sí mismo, conquistarse, enseñorearse o "llegar a ser el que se es"; al costo que sea modificar la estrechez de consciencia de un mundo aprisionado en la miseria de la moralina cristiana y la visión de tiempo que le es propia.

El objetivo, entonces, será remontarse a esas alturas simbolizadas en las montañas que habita Zaratustra, el reino de los hiperbóreos, o la patria del super - hombre, embriagado en un vuelo que indistingue la dicotomía arriba/abajo también. Un trance en el que lo más elevado coexiste con lo más anodino y nimio, y esto si se sigue la pista del asunto del descenso, esa caída, ese "hundise en su ocaso" [Untergehen] con el que inicia Así habló Zaratustra. Un alejarse de todos para compenetrarse con ellos, para llevarles la nueva del super hombre y predicar, siempre de modo paródico, efectista y "meta- irónico", teatral en suma, dionisíaco y artístico, la doctrina del eterno retorno.

El siempre inminente advenimiento de ese enceguecedor rayo que es el super-hombre, ese esplendor de temporalidad intensiva y sobrecogedora, ese Acontecimiento decisivo y siempre imperceptible, inaudito y mínimo. Se vislumbra un alejarse de todos para volver a ellos, como será claro en el siguiente apartado, con base en la narrativa de cinco momentos escogidos del ir y venir de Zaratustra a su soledad.

Un ir y venir de Zaratustra a los hombres, esa será la apuesta, descender a ellos y su atmósfera de mediocridad insoportable, pero también emerger de esa miseria para curarse y decantar aún más su sabiduría de montaña, esa sabiduría animal o bestial que destilan sus animales como guías y maestros de Zaratustra. Por eso, se afirma que el ascenso de Nietzsche y en este caso ya de Zaratustra es hacia abajo, especie de caída contra-picada o ascensional, en ese estar y no estar solo que caracteriza la narrativa del libro, una cierta indecisión entre el asco a los humanos y sobre todo a ese "pulgón" que es el "último hombre" o incluso a los llamados "hombres superiores", y la necesidad de entregarles su sabiduría. Una oscilación indecidible entre alejarse de todos para mejor llegar a ellos, apartarse con el fin también de depurarse a sí mismo y luego enceguecer, trastornar y transmutar las tablas de valores veneradas hasta ahora.

Este aspecto de depurarse a sí mismo, enfocado desde la necesidad de hacer "confesiones" para lograr una salvación ulterior o una transmutación, lo aborda Derrida con este tono:

Todo Robinson Crusoe se puede leer, por lo tanto, como un libro de confesión, como unas confesiones, dentro de la tradición agustiniana o rousseauniana. Es como si, cual anacoreta, Robinson Crusoe se retirase a una isla, a una isla que sería un desierto humano, incluso un convento o un monasterio, un lugar de retiro, como si encallase en una isla para contar sus pecados, sus fracasos pasados, sus encalladuras o sus embarrancamientos, sus derrotas y desfallecimientos, y para 
preparar el perdón, la reconciliación y la redención, la salvación. Para recuperar una relación auténtica y apropiada consigo, Robinson Crusoe confiesa sus pecados al contar su vida. (Derrida, 2011, p. 115)

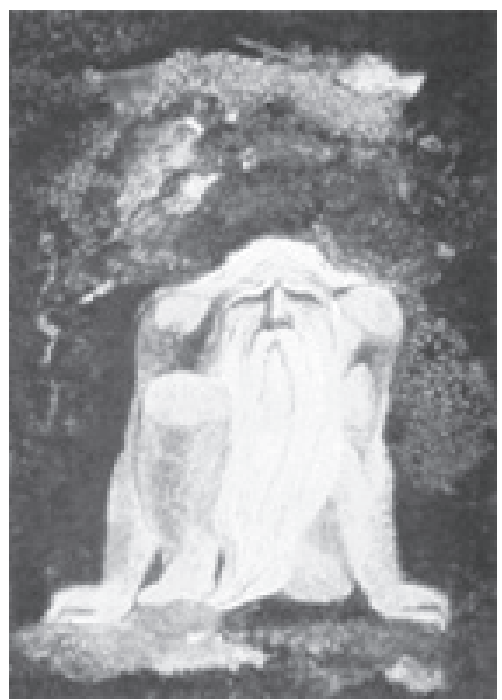

El Rey Urizen en la noche saturnal. Fuente: Blake (2013, p. 300).

In howlings \& pangs \& fierce madness,

Long periods in burning fires labouring

Till hoary, and age-broke, and aged,

In despair and the shadows of death ${ }^{32}$

The first book of Urizen III, 6 (Blake, 1998, p. 178).

La noche saturnal de Urizen de esta acuarela, nuevamente por mano de William Blake, puede compararse a esta fase de depuración ya mencionada y a propósito de la cual Derrida justifica la escritura de un libro como las Confesiones de San Agustín, las de Rousseau o el mismo Robinson Crusoe, de Daniel Defoe.

Es decir, se establece una relación capital entre aislamiento y escritura, pero no cualquier aislamiento ni cualquier tipo de escritura; se trata de un aislamiento que busca una transmutación, cuyo medio es una escritura que narra la propia vida, cuenta sus peripecias y no tiene escrúpulos para exponer sus miserias, debilidades y faltas, aunque también su grandeza indómita.Una exposición de sí mismo en sus detalles más oscuros, tal como ocurre con Zaratustra a lo largo del libro, pero también de manera privilegiada en Ecce Homo, texto al que se volverá en la última parte de este capítulo.

32 "Torturado, gritando, en locura indecible, A través de los siglos, entre fuegos horribles; Hasta que encanecido, avejentado, vencido por los años, Quedó desesperado entre sombras de muerte".

El primer libro de Urizen III, 6 (Blake, 1998, p. 179) 
En esta cuarta alegoría visual, se aprecia a Urizen anciano en un fondo oscuro y lúgubre, un viejo que no en vano representa al "Dios autoritario del antiguo testamento", ese soberano irascible y presto a prodigar los peores y más dolorosos castigos, quizá envenenado por un angustiante sentimiento de soledad, este severo monarca se encuentra en el interior de una suerte de caverna o bajo el peso de tremendas fuerzas tectónicas, petrificado y casi aplastado por su propia Razón.

Quizá también aplastado y por la linealidad temporal de la que carecía en el Aión o eternidad que antes habitaba, que él mismo era antes de escindirse en Urizen y Los, esa esfera no corpórea que ha trocado por lo "sólido", por este encierro solo y terrible en los laberintos y concavidades sórdidas de la materia: un "horizonte" aislado de la "libre fluctuación de energías" de su estado anterior.

La imagen se inserta en la parte dedicada a la "noche saturnal" en cuanto oscurecimiento o ensombrecimiento necesario, como fase del opus u obra alquímica, opus nigrum, nigredo, putrefacción de la prima materia o melancolía del ánimo ${ }^{33}$. En este caso encierro y soledumbre exacerbados, así se cita a Jacob Boheme en el Museo Hermético de Alquimia y Mística, justamente en la página en que se encuentra esta figura:

El Dios Creador de Blake, un viejo de barba blanca llamado Urizen (nombre derivado de your reason y horizon) encarna lo que Novalis llama "razón petrificante". Bajo la forma del Dios autoritario del antiguo testamento, añorante de lo "sólido", creó la materia como un parapeto frente a la eternidad, que Blake imaginaba como una libre "fluctuación" de energías. Urizen es el principio saturnal de "desecación de fuerzas, de donde surge la corporeidad", y el mundo que ha creado es un "encierro de la vida" (Roob, 1997, p. 192)

Desde estas ideas se intentará para finalizar esta parte, justificar la relación establecida entre Nietzsche, la experiencia de la soledad, Así habló Zaratustra y la Alquimia, relación que rastreada a partir de un recorrido por las imágenes del Libro de Urizen de William Blake, de acuerdo a un par de cartas escritas por Nietzsche en el tiempo de alumbramiento del Zaratustra, así como en otra de 1888 y un fragmento póstumo de ese año.

En la primera, dirigida a Franz Overbeck el 25 de diciembre de 1882, y de la que se extrajo la frase que sirve de epígrafe a este apartado, se dice:

Yo tenso cada fibra en el esfuerzo por superarme - pero he vivido demasiado tiempo en soledad, y he consumido mis "reservas" hasta tal punto que, más que cualquier otro, ahora estoy condenado al suplicio de la rueda de mis mismos

33 Sin perjuicio de abordar el tema de la Melancolía en el tercer apartado de este capítulo, encontramos esta cita de C.G. Jung en Alquimia y Mistica que justifica la relación que acaba de plantearse entre opus nigrum (como fase de la obra de transmutación alquímica) y sentimiento de opresión melancólica: "Aquí se expresa tal vez la experiencia de la nigredo, el primer estadio de la obra que se sentía como melancholia y que, psicológicamente, corresponde al encuentro con la sombra" (Jung, 2005, p. 38). 
afectos. ¡ $\mathrm{Si}$ al menos pudiese dormir! - pero las dosis más fuertes de mis somníferos me dan muy poco resultado, así como mis caminatas de 6 - 8 horas.

Si no consigo inventar el artificio de los alquimistas para transformar este fango en oro, estoy perdido. iiiAquí tengo la oportunidad más bella para demostrar que, para mí, “toda vivencia es útil, todo día sagrado y todo ser humano divino”!!!

Todo ser humano divino. (Nietzsche, 2010, p. 306)

La frase que más resalta aquí es traducida por Germán Cano en una nota aclaratoria de su edición de El Anticristo de la siguiente manera: "Estoy perdido como no encuentre el secreto de los alquimistas para transformar esta porquería en oro" (Nietzsche, 2000, p. 127). Esa "porquería" es la prima materia; unas líneas antes de esta cita, en la misma carta, se dice: "He sufrido como por una locura a causa de las experiencias insultantes y penosas de este verano [...]. Se trata de un conflicto de afectos opuestos, que no soy capaz de afrontar" (Nietzsche, 2010, p. 306).

Vemos, entonces, que ese "fango" o "porquería" a transmutar está constituido por una serie de asuntos desagradables y penosos, incluido el terrible insomnio que estos le han provocado, lo interesante aquí es la alusión directa a los alquimistas y al proceso de transmutación, que ha sido tan importante para hablar de una "transmutación de todos los valores", tarea última que se impuso Nietzsche. El conocimiento del opus magna alquímico, el proceso para convertir lo más bajo y ruin en oro en su propio cuerpo es algo destacable en él, su propia vida es ese proceso, y según las ideas expuestas en este apartado, en particular, su obra sería la transmutación de la dura experiencia de la soledad en su escritura.

En la segunda carta a que nos referimos, también a Overbeck, y que data del 17 de agosto de 1884, se percibe aún con mayor claridad la relación entre aislamiento —en este caso familiar - y la transformación áurea que se espera lograr de todo ello:

Es evidente que no me toca a mí "justificarme", desde el momento en que he ido más allá de los límites de las virtudes humanas, no soy capaz de ello; pero quizás, precisamente por esto, he estropeado de raíz la relación con mis familiares. Si no sintiese que ahora estoy aislado por todos lados, no sufriría tanto por esta fractura con mis parientes. In summa: forma parte de mis deberes dominar también esto y continuar "transformando en oro" cualquier cosa que me toque en suerte, en beneficio de mi TAREA. (Nietzsche, 2010, p. 472)

La última carta, ya de 1888, parte de un borrador incluido en los fragmentos póstumos de la primavera - verano de 1888, concretamente el numerado 16[43], en que se hace una apología de la persona del alquimista, allí se sostiene:

El hacedor de oro es el único verdadero bienhechor de la humanidad.

Que se transvaloren valores, que de lo poco se haga mucho, de lo ínfimo se haga oro: la única especie de bienhechores de la humanidad 
ellos son los únicos enriquecedores

los otros no son más que cambistas

Imaginemos un caso extremo: que hubiese algo odiado, condenado en sumo grado y que precisamente eso se convirtiese en oro: ése es mi caso. [...] (Nietzsche, 2008, p. 683)

La carta, que retoma las ideas fragmentariamente expuestas en las anteriores líneas, es dirigida a Georg Brandes el 23 de mayo de 1888, pero en ella se halla mejor elaborado el tema del alquimista por oposición a los hombres que "simplemente dan cambio", el texto dice así:

En realidad el alquimista es el tipo de hombre más excelente que existe, es decir, el hombre que de algo ínfimo y despreciable hace algo valioso, hasta el mismo oro. Por eso sólo este hombre enriquece; los demás hombres únicamente dan cambio. Mi labor es esta vez muy curiosa. Me he preguntado: ¿qué es lo que ha sido hasta ahora más odiado, temido y despreciado por la humanidad? Y de ello he hecho mi "oro". Ahora solo falta que no se me acuse de falsa moneda. Aunque también esto lo harán, seguramente. (Nietzsche, 2000, pp. 30-127)

Aquello que en este documento se caracteriza como lo más "odiado, temido y despreciado", la prima materia, es entendido aquí como la soledad, pero también la experiencia del desprecio o la indiferencia decantada, acrisolada o aquilatada por la soledad. Una circunstancia dolorosa pero muy propicia en esa afinación y metamorfosis de sí mismo, una verdadera transmutación alquímica como la visualizábamos en las figuras del libro de Urizen de William Blake, particularmente su fase de nigredo en la última imagen. Tan difícil experiencia la encontramos mencionada en un borrador del 25 de diciembre de 1882: "Yo tenso cada fibra en el esfuerzo por superarme - pero- una soledad tan prolongada es demasiado para una persona" (Nietzsche, 2010, p. 306).

De este recorrido por la soledad de Nietzsche como autor se pasa ahora a revisar cinco momentos de la soledad de Zaratustra como doble de Nietzsche, como personaje y emanación; penetrando así en el tinglado, en la puesta en escena y transubstanciación de la soledad de Nietzsche a través de la escritura de su obra capital. 


\subsection{CINCO MOMENTOS EN EL RECORRIDO SOLITARIO DE ZARATUSTRA}

\section{Primero}

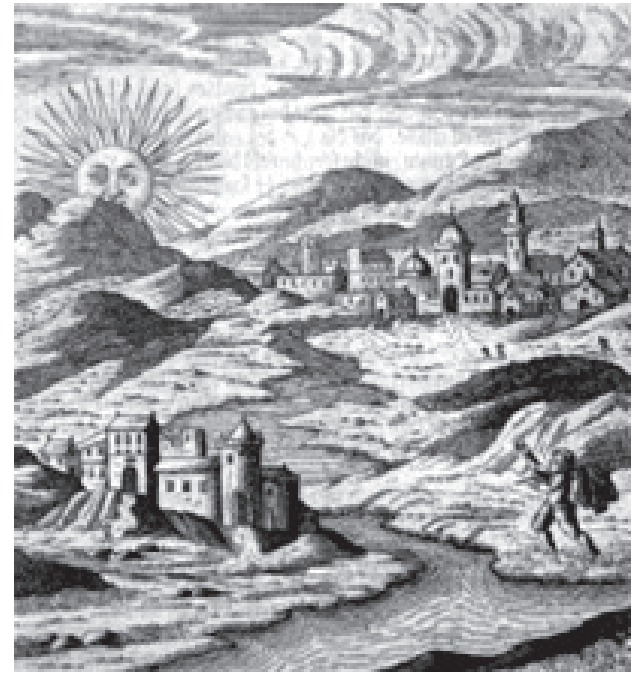

El peregrino

Salomon Trismosim, Aureum vellus, Hamburgo, 1708

Cuando Zaratustra tenía treinta años abandonó su patria y el lago de su patria y marchó a las montañas. Allí gozó de su espíritu y de su soledad y durante diez años no se cansó de hacerlo. (Nietzsche, 2006, p. 33)

Es posible poner en resonancia este inicio de Así habló Zaratustra, que presenta la decisión del personaje de abandonar su patria y todo lo que le es conocido, con la del propio Nietzsche en una carta enviada desde Menton a su hermana a finales de 1884 en la que dice: "Que ahora no se me acerquen conocidos: necesito esta calma absoluta" (Nietzsche, 2010, p. 501).

Esta misiva repite esa determinación de aislarse abordada en el anterior apartado, como casi siempre que Nietzsche se refiere al tema de tener compañía, apreciamos una reiteración de dejar todo atrás pensando en la realización de su tarea, la decantación de sus ideas y posterior escritura de su Opus.

Como en la imagen del peregrino, también de resonancias alquímicas, se toma una decisión soberana: "Estoy solo, sola', quiere decir, por lo demás, 'soy' absoluto, 
es decir, estoy absuelto, despegado o liberado de cualquier atadura, absolutus, exento de cualquier atadura, soy excepcional, incluso soberano" (Derrida, 2011, p. 21). Esta búsqueda de soberanía ya era evidente en la primera parte en que dominaba la imagen del combate iniciático con la bestia, el sentido de tal batallar ciclópeo era justamente conquistar esa libertad para crear nuevos valores, ganársela luchando, venciendo los monstruos morales que pretendían erigirse como guardianes severos de una tradición.

Comentando Robinson Crusoe, a propósito de insularizaciones forzadas o elegidas, el seminario continúa diciendo:

El libro es una larga explicación de Robinson con muchas bestias. Y justamente su teatro es, indisolublemente, un teatro de la soberanía solitaria, de la afirmación de dominio (de sí, sobre los esclavos, sobre los salvajes y sobre las bestias, sin hablar, puesto que justamente se trata de no hablar de ellas en modo alguno, de las mujeres) (Derrida, 2011, p. 52).

Así se conecta el sentido de la pregunta por la soberanía con una pesquisa sobre la soledad como medio a través del cual se puede acceder a cierto poder, distinguiendo esta vez aquellos (o aquellas) sobre las que se ejerce tal dominación, pero también relacionando retiro y auto-dominio como consecuencia de esa majestad que distingue y singulariza.

Zaratustra inicia un vagabundeo de consecuencias imprevisibles, un nomadeo que lo arranca de las certezas de una vida sedentaria y lo arroja a la exploración de posibilidades insospechadas, señalando así un cambio de estatus de suma importancia: se convierte en un buscador, en alguien para quien los modos constituidos de dar sentido a las cosas se revelan insuficientes y debilitantes, en últimas, esta primera partida simboliza el riesgo de fraguarse una mirada distinta, aceptar el peligro de abandonar los criterios valorativos usuales, un deshacerse de muletas morales o de otra índole y atreverse a pensar y ver el mundo de otra forma.

Zaratustra se desliga de su vida anterior, de la cual no se sabe nada, pero de la cual son intuibles las razones por las que es depreciada en favor de esa soledad que resulta tan benéfica y transubstanciadora: “ $\mathrm{i}$ Mira, estoy hastiado de mi sabiduría como la abeja que ha recogido demasiada miel, tengo necesidad de manos que se extiendan" (Nietzsche, 2006, p. 33). En tal apartamiento su sabiduría ha crecido y se ha acumulado como la miel, ese alejamiento de todo ha dado frutos, ha generado un tipo de conocimiento frente al cual se ve en la necesidad de comunicarlo, transmitirlo: "Me gustaría regalar y repartir hasta que los sabios entre los hombres hayan vuelto a regocijarse con su locura, y los pobres con su riqueza" (Nietzsche, 2006, p. 34).

Esta sabiduría enloquecedora, o por lo menos capaz de festejar la locura en los sabios, como un pharmakon ambiguo este saber "para todos y para nadie" es polisémico: embriagador o enfermante. Ya se verá hasta qué punto puede ser incluso despreciado por la multitud. 
Pero hay una característica central, esa miel fecunda debe ser regalada, otorgada como un don, así le dice luego al anciano del bosque "iQué dije amor! Lo que llevo a los hombres es un regalo" (Nietzsche, 2006, p. 35). Se trata de una "virtud que hace regalos" como se dirá en el último discurso de la primera parte, un darse gratuito, un desbordamiento, un otorgar excesivo que borra toda medida.

Seguido al aislamiento, entonces, viene un momento opuesto en que Zaratustra anhela la compañía de discípulos, compañeros, oídos atentos para sus enseñanzas largo tiempo maduradas. Siempre frente a la majestad enceguecedora y omniradiante del sol, como escenografía grandiosa para este inicio también grandioso del libro, dice: "para ello tengo que bajar a la profundidad: como haces tú al atardecer, cuando traspones el mar llevando luz incluso al submundo, jastro inmensamente rico!" (Nietzsche, 2006, p. 34).

El volver a los hombres se equipara a un descenso terrible, una travesía por el inframundo como en la narrativa tradicional en que todo héroe - Hércules, Orfeo, Ulises etc.- debe soportar un tiempo con las potencias ctónicas o infernales, venciendo las dificultades inherentes a una visita al reino de la muerte.

Es de resaltar que ahora ese infierno o experiencia dolorosa y difícil no corresponde a la soledad como tal, en el tono sugerido en el anterior apartado, sino que se trata de su vuelta al mundo de los hombres. Ese descenso tiene que ver con el retorno a la "gran ciudad", a la compañía de sus semejantes, sigue diciendo en tono embriagado Zaratustra al sol con quien se está equiparando: "Yo, lo mismo que tú, tengo que hundirme en mi ocaso [untergehen], como dicen los hombres a quienes quiero bajar" (Nietzsche, 2006, p. 34).

Este descendimiento tiene que ver, entonces, no solo con la imagen física de bajar de las alturas a las que se ha encumbrado, un "bajar" geográfico de su montaña a los valles en que se hallan los demás seres humanos, sino con un simbólico "mezclarse" con aquellos de quienes había abjurado al tomar la primera decisión de irse, de apartarse, de dejar para aquilatar ese conocimiento hiperbóreo, de montaña gigante, áureo como el sol a quien dedica sus primicias.

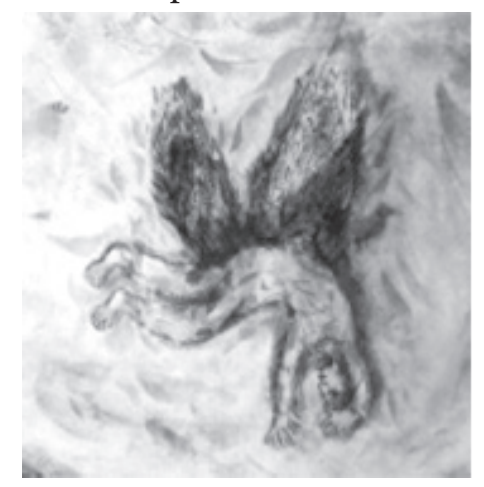

La caída de Ícaro, Marc Chagall, 1975, detalle. 
Como en el motivo teológico de la "caída" este "hundirse en su ocaso", Untergehen, implica o se involucra con la acción de abandonar una condición prístina y acceder a la contaminación de la materia, el tiempo lineal, la corrupción y la muerte. La interesante nota aclaratoria de Andrés Sánchez Pascual a la traducción castellana de untergehen nos dice: "Es una de las palabras-clave en la descripción de la figura de Zaratustra" (Nietzsche, 2006, p. 444).

Como si este movimiento descendente, simbolizado en el ocaso del sol que abandona el mundo de la luz para entregarse y perderse en regiones subterráneas, de alguna forma definiera no solo las travesías y peripecias de Zaratustra, sino yendo incluso más allá de la mera dimensión descriptiva, fuera parte de su ser mismo, una figura que conoce el momento radiante y luminoso del mediodía, pero también el atardecer y el misterio propio de la noche.

Sobre este sentido se dice en la nota mencionada: "pasar al otro lado" es superarse a sí mismo y llegar al super-hombre, el tránsito del sol por la oscuridad tiene que ver con una superación de sí mismo, al igual que en el caso de Zaratustra, su "descenso" a la compañía de sus congéneres lo haría autosuperarse, transmutarse en ese rayo enceguecedor y vertiginoso que sería el "super-hombre". Aquí Andrés Sánchez Pascual recensiona el plexo de significados a que da lugar esta palabra compuesta por Nietzsche, este Unter-gehen polivalente, no solo indicando ese "caminar hacia abajo" y la "puesta del sol u ocaso", sino añadiendo una tercera posibilidad que resulta sumamente relevante en este análisis.

La reflexión es enunciada en estos términos: "Untergehen y el sustantivo untergang se usan con el significado de hundimiento, destrucción, decadencia”, añadiéndose enseguida: "Zaratustra se hunde en su tarea y fracasa. Su tarea, dice varias veces, lo destruye" (Nietzsche, 2006, p. 444). Se ve cómo su "caída", como quedó dicho iniciando este párrafo, emparenta el gesto del personaje con la muerte, como en el pasaje bíblico del génesis, hace que quien la sufre, como una expulsión del paraíso, empiece a padecer las consecuencias del abandono de la eternidad, la descomposición, la corrupción en las garras del implacable tiempo lineal y cronológico ${ }^{34}$. Con esto, se ejemplifica el fracaso terrible en la enorme tarea que se ha propuesto Zaratustra, como es evidente en la escena en el primer pueblo, con la "caída" estrepitosa y posterior deceso del volatinero, allí donde la multitud desprecia sus enseñanzas y pide diversión, iniciando esa serie de desencuentros que no cuesta trabajo relacionar con los desencantos y dificultades en la propia vida del propio Nietzsche y de los cuales da cuenta la correspondencia referenciada.

Como un salto al abismo asociamos este momento de hundirse en su ocaso al retorno a la vida en común, luego del cual, y como saciado o incluso asqueado de sus congéneres, Zaratustra retorna a las delicias de su añorada soledad.

34 Algo como lo que ocurría a Urizen en la cosmogonía de William Blake. 


\section{Segundo}

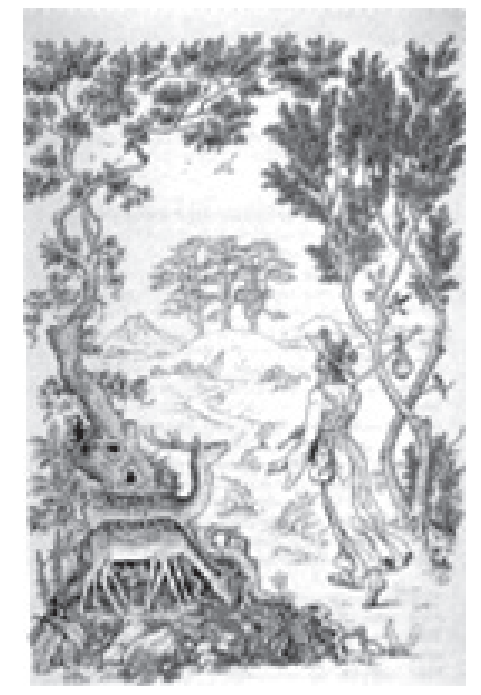

El peregrino vuelve a su soledad

Johann Valentin Andreae, Die Alchimysche Hochzeit von Christian Rosenkreuz (1616)

Cuando Zaratustra se hubo despedido de la ciudad que su corazón amaba y cuyo nombre es "La Vaca Multicolor" le siguieron muchos que se llamaban sus discípulos y le hacían compañía. Llegaron así a una encrucijada: allí Zaratustra les dijo que desde aquel momento quería marchar solo, pues era amigo de caminar en soledad. (Nietzsche, 2006, p. 122)

En el fin de la Primera parte, la narración describe el nuevo retorno de Zaratustra a la soledad. Como si ya hubiese tenido suficiente de su contacto con los seres humanos, mostrándose añorante de estar consigo mismo, sin embargo, ya ha trabado lazos de amistad, además de la compañía siempre vivificante y sabia de sus dos animales alegóricos, ahora tiene seguidores: "Y sus discípulos le entregaron como despedida un bastón en cuyo puño de oro se enroscaba en torno al sol una serpiente (Nietzsche, 2006, p. 122).

Andrés Sánchez Pascual añade en este punto una nota explicando que "este bastón, con su simbolismo de la serpiente alude al cetro de Esculapio, dios de la medicina en la antiguedad griega" (Nietzsche, 2006, p. 455). Con referencia a la virtud de la que habla el título del capítulo y explicando el simbolismo del bastón, Nietzsche añade más adelante: "Poder es esta nueva virtud, un pensamiento dominante es, y, en torno a él, un alma inteligente: un sol de oro y, en torno a él, la serpiente del conocimiento" (Nietzsche, 2006, p. 124). 
El poder de la idea que se ha enseñoreado de Zaratustra es posible asumirse (además de ese "dar regalos" y "prodigarse" creativo y lúdico, iconoclasta sin reservas, del que habla la primera parte de ese apartado) también como la atracción del aislamiento. Esa idea soberana sería la soledad, una soledad ya depurada después de este primer ciclo de aventuras entre los hombres, por eso alrededor se enrosca ahora "la serpiente del conocimiento".

En este orden de ideas, el bastón vendría a simbolizar la soledumbre decantada de un querer retirarse de todo trato humano, pero luego de haber experimentado la compañía de sus semejantes. Lo anterior también se sustenta en las numerosas alusiones de Nietzsche a la soledad como cura, estudiadas en el anterior acápite, y si este bastón además tiene que ver con Esculapio y la antigua medicina griega, con más razón puede revestirse de este significado. Nuevamente acerca de la soledad, en "La virtud que hace regalos", el tono y las palabras de Zaratustra asumen un cariz celebratorio, profético, siempre grandilocuente:

Vosotros los solitarios de hoy, vosotros los apartados, un día debéis ser un pueblo: de vosotros, que os habéis elegido a vosotros mismos, debe surgir un día un pueblo elegido: - y de él, el super-hombre. (Nietzsche, 2006, p. 126)

Siempre antagónico con la idea de "rebaño", el anterior fragmento resulta de suma importancia a la hora de desentrañar el sentido que tiene la soledad ya no solo para el autor del texto, Nietzsche mismo, sino para Zaratustra. La celebración de la soledad toma una dimensión insospechada, no es vista como una instancia de apartamiento y desconexión de los seres humanos entre sí, sino como posibilidad de constituir lazo social, como manera de agrupar a los "espíritus libres", todos aquellos que como él, han renegado de las comodidades y mal olor de una comunidad cuyo horizonte son verdades inmutables y sacrosantos postulados sobre lo "bueno" y lo "malo".

El carácter paradójico de estas afirmaciones se acentúa toda vez que el gregarismo de nociones como "pueblo" o "nación" queda sobreexpuesto y como en ridículo al proponerse un antinómico "pueblo elegido" conformado por solitarios y recalcitrantes; los indómitos, lúcidos y desafiantes habitantes de su propia manera de ver las cosas.

No es menos llamativo el carácter "autoelegido" de esta extraña congregación de singularidades, que se separa radicalmente de la "moral de rebaño" subyacente en toda idea de "elección divina", siempre dependiente de un otro absoluto y sojuzgador, quien toma las decisiones acerca de quién se salva y quién no. En este caso, la apología es a aquellos solitarios que han vencido los monstruos interiores y exteriores de esta forma de valorar y unidos en esa común desfascinación se unen para procrear al super-hombre, una multiplicidad de artistas de sí mismos y no una caterva determinada por la moral del pastor de turno.

Por lo anterior, es tan importante la soledad, constituida ahora en un modo de auto-empoderamiento capaz de trocar la actitud obsecuente en voluntad de poder in-encasillable y configuradora de mundos. Así la burla a las prescripciones religiosas 
dirigidas al "pueblo elegido" alcanza su cénit, la parodia es total a la imagen salvífica de Dios o cualquier otra instancia trascendente, Estado, Ciencia o Historia, que aseguraba el sentido, el piso explicativo y el orden de los acontecimientos para todos. Ahora se trata de una sumatoria de transfigurados reacios a ser catalogados como "pueblo" en sentido tradicional, que rehúyen vigorosamente las clasificaciones y nomenclaturas aún dependientes de esos anquilosados "monstruos morales". Luego de lanzar estas palabras proféticas y despiadadas, casi como calculando el tremendo efecto que van a causar sobre sus "discípulos", Zaratustra se retira diciendo:

¡A hora me voy solo, discípulos míos! ¡También vosotros os vais ahora solos! Así lo quiero yo. En verdad, éste es mi consejo: ¡Alejaos de mí y guardaos de Zaratustra! Y aun mejor: ¡Avergonzaos de él! Tal vez os ha engañado. (Nietzsche, 2006, p. 126)

La invitación y el ánimo de sospecha lo invaden todo, incluso la figura del propulsor de esa misma sospecha, la des-construcción de cualquier forma de autoridad trascendente que no sea consecuencia de la voluntad transmutada de cada cual es muy fuerte, que no haya crecido en los parajes inhóspitos del alejamiento de las tablas valorativas tenidas por obvias, esa exploración interior y esa confrontación con el "sentido común" históricamente vigente.

Por eso, vuelve Zaratustra a su soledad, de nuevo busca la interrupción de lo asumido como verdadero hasta ahora, el rompimiento con el circuito de comodidades y rutinas dado por descontado en cualquier horizonte compartido, tributario siempre de algún metarrelato que legitima pero también cristaliza las infatigables posibilidades de la voluntad de poder. Respecto a la vida de Nietzsche, este momento de vuelta al frío y duro manto protector de la soledad se vislumbra en esta carta enviada a Franz Overbeck el 22 de febrero de 1883:

Siguiendo el camino ya recorrido, en el máximo apartamiento, quiero buscar mi salud. Mi error el año pasado fue renunciar a la soledad. Mi exclusiva convivencia con imágenes y fenómenos ideales me ha vuelto tan irritable que en las relaciones con los seres humanos actuales padezco sufrimientos increíbles y un enorme sentimiento de privación; acabo haciéndome duro e injusto; en suma, es algo que me hace daño. (Nietzsche, 2010, p. 326)

El anterior documento resulta muy pertinente por cuanto se refiere al haber "renunciado" a la soledad como un terrible error, en el caso de la narrativa de Zaratustra, no sería exacto decir que en esta primera parte su contacto con los hombres fue un "error", aunque veremos cómo el mismo Zaratustra se queja frecuentemente de no encontrar los oídos adecuados para sus potentes e hiper-sutiles palabras: "ahí están', dijo a su corazón 'y se ríen: no me entienden, no soy boca para estos oídos"” (Nietzsche, 2006, p. 40).

Es por estas razones que llega a exclamar enseguida, con gran rabia e indignación: “¿habrá que romperles antes los oídos, para que aprendan a oír con los ojos?”. Como si el desencanto al no hallar respuesta en sus contemporáneos lo obligara a buscar 
soluciones extremas. La misiva a Overbeck describe muy bien la incapacidad de Nietzsche para soportar a sus semejantes, luego de convivir tanto tiempo únicamente "con fenómenos ideales" le resulta demasiado difícil sintonizarse con la materialidad tosca y cotidiana de los demás.

Nietzsche sufre mucho al compartir con sus semejantes, se ofusca, se vuelve "duro e injusto", como si ya estuviera completamente deshabituado y por ende incapacitado para resistir sin irritarse las nimiedades en que viven otros seres humanos. Incluso el "sentimiento de privación" que lo oprime no es consecuencia de estar solo, sino de compartir con otros; es allí donde se siente privado, arrancado de la compañía dura, exigente pero fecunda de su soberana soledad.

\section{Tercero}
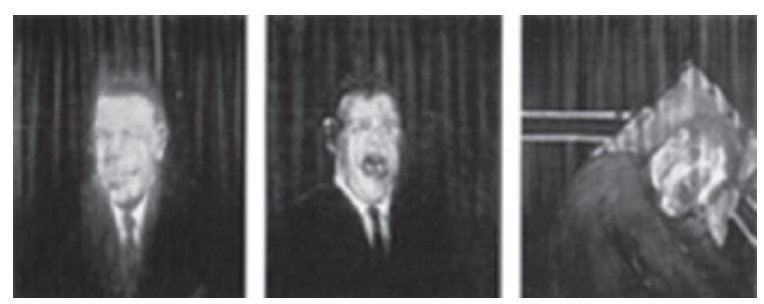

Visiones, borrones y anamorfias en el espejo

Francis Bacon, Tres estudios de cabeza humana, 1953.

Iniciando esta vez la segunda parte, en "El niño del espejo" la narración retoma ese estar solo de Zaratustra al que aludíamos hace unas líneas como una suerte de respiro necesario luego del primer ciclo de aventuras y experiencias con otras personas. Valiéndose de la imagen evangélica del sembrador, se caracteriza esta espera de una manera diferente a la primera, ahora no se aquilata y espesa la miel de la sabiduría solar del profeta, sino que se aguarda el efecto que esta pueda causar en los hombres con los que ha tratado.

Sin perder de vista que todas estas son imágenes transmutadas de la propia vida de Nietzsche, quien esperaba los efectos que sus libros causarían en sus lectores, cuya paciencia tanto anhelaba y maldecía, como deseando y rechazando a la vez un público para el drama que representaba en sus escritos, visibles e invisibles en el ambiente cultural de su época. Volvemos al sentido de este aguardar solitario que quiere ver germinar algo del suelo en que con tanto dolor ha "sembrado":

Zaratustra volvió a continuación a las montañas y a la soledad de su caverna y se apartó de los hombres: aguardando como un sembrador que ha lanzado su semilla [...] Así transcurrieron para el solitario meses y años; mas su sabiduría crecía y le causaba dolores por su abundancia. (Nietzsche, 2006, p. 131) 
Este sufrimiento del exceso acumulado e hiriente de su propia sabiduría lo lleva a buscar de nuevo el trato con los demás, refiriéndose a ellos como "sus discípulos"; una vez ha renunciado, luego de la escena de la caída y muerte del volatinero en el primer pueblo, a hablar a la multitud, escogiendo un círculo pequeño de discípulos para prodigar el esplendor de sus enseñanzas.

La nota característica de este "volver" a ellos va a ser la deformación que está sufriendo su doctrina, el sueño del niño con el espejo le advierte sobre esta posibilidad, en ese espejo onírico aprecia la caricatura terrible de sí mismo: "Y al mirar yo al espejo, lancé un grito, y mi corazón quedó aterrado: pues no era a mí a quien veía en él, sino la mueca y risa burlona de un demonio" (Nietzsche, 2006, p. 131).

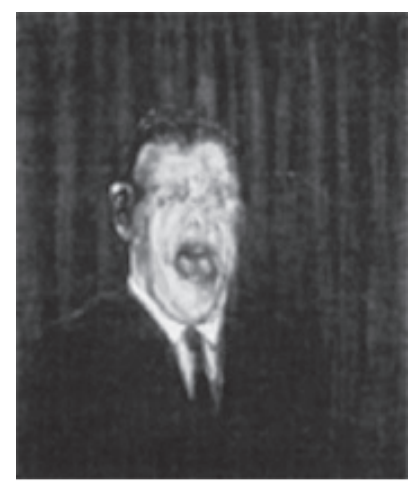

Ardid de rostro tachado

F. Bacon, Tres estudios de cabeza humana, 1953, panel central

No solo las enseñanzas de Zaratustra pueden haber caído en terreno yermo e inhóspito, imposibilitándose así su germinación y aprovechamiento, sino que su palabra está siendo desfigurada: "mi doctrina está en peligro [meine Lehre ist in Gefahr], la cizaña quiere llamarse trigo! [Unkraut will Weizen heißen!]" (Nietzsche, 2006, p. 132).

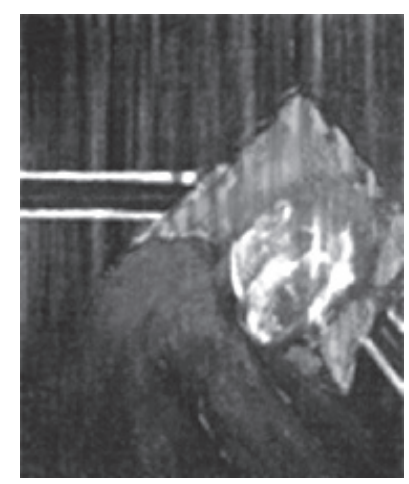

Variación de facciones desfiguradas

F. Bacon, Tres estudios de cabeza humana, 1953, panel derecho. 
"Mis enemigos se han vuelto poderosos y han deformado la imagen de mi doctrina, de modo que los más queridos por mí tuvieron que avergonzarse de los dones que yo les había entregado. ¡He perdido a mis amigos; me ha llegado la hora de buscar a los que he perdido!" (Nietzsche, 2006, p. 132). Con nítida resonancia al problema de la soledad y el cuidado a los amigos que ardua y trabajosamente ha cultivado Zaratustra, así como le "llegará la hora" más silenciosa que lo constriñe a irse, aquí la hora lo conmina a salir a su encuentro.

Esta frase nos indica que el profeta del eterno retorno no está radicalmente desinteresado por la compañía de otros. Muy, por el contrario, anhela y cuida la amistad de quienes le son queridos, por eso corre a rectificar el sentido de su doctrina, iniciando así el nuevo ciclo de peripecias que constituye la segunda parte del Zaratustra.

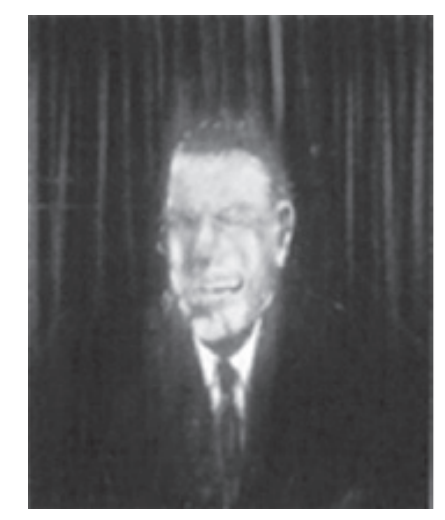

Desidentificación en el espejo del "otro"

F. Bacon, Tres estudios de cabeza humana, 1953, panel izquierdo.

\section{Cuarto}

Fortaleciendo la interpretación sugerida más arriba, en el sentido de que el pensamiento dominante para Zaratustra puede ser la soledad y el retiro del tráfico mundano e intercambio con sus semejantes, se halla en el apartado "La más silenciosa de todas las horas" (sin perjuicio de comentar de nuevo este pasaje al inicio del siguiente capítulo referido específicamente el tema de la voz, el silencio y el dominio de una o unas voces, en el interior tanto de los personajes como de Nietzsche mismo) una imagen significativa del gran dolor que le causa este nuevo retiro, sobre todo porque este no es voluntario: "Sí, una vez más tiene Zaratustra que volver a su soledad: ipero esta vez el oso vuelve de mala gana a su caverna!" (Nietzsche, 2006, p. 217). Recibiendo órdenes e incapaz de desacatarlas, se acentúa la aflicción mayor que le causa este alejamiento: 
Cuando Zaratustra hubo dicho de nuevo estas palabras lo asaltó la violencia del dolor y la proximidad de la separación de sus amigos, de modo que lloró sonoramente; y nadie sabía consolarlo. Y durante la noche se marchó solo y abandonó a sus amigos. (Nietzsche, 2006, p. 220)

Sobre este estar y no estar, quedarse e irse de Zaratustra, él mismo dice en "De la bienaventuranza no querida", como un paradójico e indefinible ir y venir entre la compañía y el abandono: "Así estoy en medio de mi obra, yendo hacia mis hijos [zu meinem Kindern] y volviendo de ellos: por amor a sus hijos tiene Zaratustra que consumarse a sí mismo" (Nietzsche, 2006, p. 234).

Como parte de este trasegar indecidible, Zaratustra se debate a lo largo del relato en momentos de una soledad inspirada: "luz soy yo: ¡ay, si fuera noche! Pero ésta es mi soledad, el estar circundado de luz" (Nietzsche, 2006, p. 163), en la "canción de la noche”, o en "antes de la salida del sol”: “¡Oh cielo por encima de mí, tú puro! ¡Profundo! ¡Abismo de luz! Contemplándote me estremezco de ansias divinas [...] ¡Oh, cómo no iba yo a adivinar todos los pudores de tu alma! ¡Antes del sol has venido a mí tú, el más solitario de todos!" (Nietzsche, 2006, p. 237), así como momentos de dramatismo y aflicción por no contar con sus discípulos y amigos, como ese sol que experimenta momentos de intensa brillantez, solo para atardecer y "hundirse" quizá amargamente en su propio ocaso.

Esta situación indecidible y ambigua se aprecia en una carta de Nietzsche a su madre, contándole sobre su compartir con amigos en la ciudad de Zúrich en octubre de 1884. Heinrich Köselitz ha decidido vivir por un tiempo en esa ciudad y han pasado veladas muy agradables con otros conocidos (se menciona a una señora Köckert, entre otros), pero en la carta, como en el pasaje "De la más silenciosa de todas las horas" algo jala o saca a Zaratustra de su idilio con los otros, una fuerza más poderosa lo obliga al retiro, como ese daimon trágico del que habla Stefan Zweig en su biografía La lucha con el demonio (Zweig, 1934, pp. 217-304), parece ser un duende amargo empeñado en fastidiar la vida del escritor, pero que también representa su genialidad desbordante y abismal.

Si ese demonio con el que no se cansa de luchar Nietzsche es también la soledad, ésta no deja de aplastarlo pero igualmente de otorgarle sus dones más exquisitos, ese demonio que lo demuele pero incrementa sus niveles de consciencia y sensibilidad hasta hacerle concebir (o incluso "susurrarle", si se sigue con la metáfora del daimon y la voz dominante) ideas como el "eterno retorno".

Imágenes de pesadilla y de una lucidez tenebrosa, como una suerte de sino trágico, indefectible, pero también por su poética magnífica y embriagante. Este puede ser el "espíritu" al que se refiere en la carta que ahora evocamos, una necesidad francamente incontrastable, un magnetismo sobrehumano que lo guía no siempre a lugares de luz y placidez, sino que sabe pasearlo por horrores que (a juicio de S. Zweig, por poner un ejemplo), lo conducirán a la insania y el oscurecimiento total de sus facultades mentales. 
Mencionando, entonces, el carácter curativo de ese compartir momentáneo con Köselitz, sostiene el autor de Zaratustra, en confesión a Franzizska Nietzsche: "Realmente tu hijo se ha repuesto mucho durante este tiempo, pero me resultaría absolutamente imposible vivir así cuando de nuevo 'el espíritu me asalta': Él me exige: soledad." (Nietzsche, 2010, p. 495).

\section{Quinto}

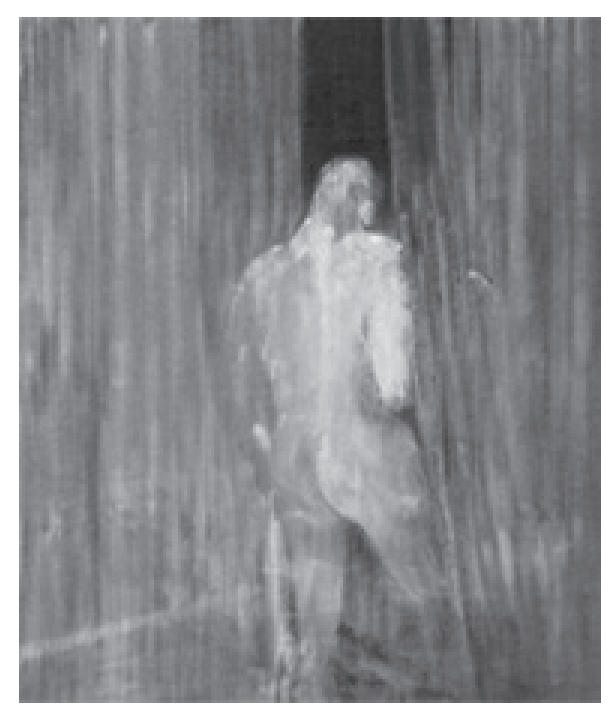

Francis Bacon, Estudio de cuerpo humano, 1949

En este último momento, y tras la estela fantasmagórica de una figura de Bacon como desapareciendo tras una cortina de transparencia e insinuada o intangible opacidad, seguimos la narrativa de Zaratustra cuando iniciando la tercera parte, el caminante, el vagabundo, el peregrino al que nos hemos venido refiriendo, inicia un recorrido espectral, nocturno y especialmente difícil en su búsqueda: "fue alrededor de la medianoche cuando Zaratustra emprendió su camino sobre la cresta de la isla" (Nietzsche, 2006, p. 223).

En este retirarse vamos a ver cómo se desliza la aparición de la doctrina del Eterno Retorno, en una seguidilla de situaciones que hacen indistinguible por momentos la "realidad" de la visión y la escena onírica, por eso es tan importante la introducción y la atmósfera de silencio y nocturnidad que envuelve la narrativa. Se perciben taciturnos ciertos pensamientos que se vierten sobre Zaratustra haciendo énfasis en la importancia del recorrido que ahora está trasegando: "recorres tu camino de grandeza: ¡nadie debe seguirte aquí a escondidas! Tu mismo pie ha borrado detrás de ti el camino, y sobre él está escrito: Imposibilidad" (Nietzsche, 2006, p. 224); con estas palabras se cierra en torno del personaje cualquier encuentro con sus discípulos 
o amigos, cualquier soporte o acompañamiento de ellos. Se alude a la "grandeza" de esta opción solitaria, mientras Zaratustra mismo explicita lo que pasa por su mente:

Así iba diciéndose Zaratustra a sí mismo al ascender, consolando su corazón con duras sentezuelas: pues tenía el corazón herido como nunca antes. Y cuando llegó a la cima de la cresta de la montaña, he aquí que el otro mar yacía allí extendido ante su vista: entonces se detuvo y calló largo rato. La noche era fría en aquella cumbre, y clara y estrellada.

Conozco mi suerte, se dijo por fin con pesadumbre. ¡Bien! Estoy dispuesto. Acaba de empezar mi última soledad.

¡Ay, ese mar triste y negro a mis pies! ¡Ay, esa grávida desazón nocturna! ¡Ay, destino y mar! ¡Hacia vosotros tengo ahora que descender! (Nietzsche, 2006, p. 225)

Hablar de "última soledad" anuncia la importancia de este recodo en su periplo, con el "corazón herido" como nunca antes, se deja sentir la suprema desazón que lo envuelve, arropándolo, circunscribiéndolo y aislándolo con una clarividencia de intuiciones enigmáticas, así como ha dicho de la pintura de Francis Bacon - que abre este quinto momento- Luigi Ficacci, historiador italiano del arte y experto en tendencias contemporáneas:

En estudio de cuerpo humano el cuerpo es una masa cromática blanquecina plasmada sobre el fondo ocre del lienzo. El lienzo es parte activa del compuesto cromático que rodea la figura, junto con el intersticio negro al que ésta se dirige y con la lluvia de trazos verticales, del gris perla al gris plomo, de la cortina que atraviesa para desaparecer. (Ficacci, 2010, p. 31)

Se veía ya la intención de "desaparecer" que Nietzsche había manifestado en su correspondencia del periodo, ahora el turno es para Zaratustra. Es posible imaginarse su figura penetrando la indecisión de ese retazo negro en la pintura de Francis Bacon, una "masa blanquecina" que progresivamente se va afantasmando, como observábamos en los rostros que incluíamos en el tercer momento, los bordes pierden nitidez y mínimos borrones se adueñan de la figura, transfigurando la precisión de las facciones en una bruma que crea efectos sorprendentes e inquietantes.

Lo anterior cobra especial relieve si, como justo en esta parte de la narración, Zaratustra se dirige al encuentro de un destino portentoso pero desasosegante e incierto, vagamente presentido, insinuado y abismal. Nos interesan los comentarios que hablan del "entorno" de la figura, la técnica pictórica y propiamente cromática para "hundir" la figura en un ensombrecimiento paulatino: "en la culminación del sentimiento poético del abandono de la escena por parte de la figura, desaparece en la oscuridad, tras la cortina opaca" (Ficacci, 2010, p. 31).

Esa cortina que ha sido caracterizada como una "lluvia de trazos verticales" arroja una poderosa sensación de irrealidad sobre la escena, como una ondulación perceptiva que simultáneamente constituyera el decorado y lo que se muestra a 
través de él, haciendo indiscernible el objeto atrapado en una espectralización de sí y de su entorno. En esta última despedida de Zaratustra ocurre otro tanto, la visión melancólica del mar, la luz de la luna incipiente, el frío, la altura desde la que se observa el paisaje son sobrecogedores, funcionan como una tramoya para crear el efecto requerido y lograr un "desvanecerse de Zaratustra".

Hablando del mar y conversando consigo mismo Zaratustra exclama: "Has querido incluso acariciar a todos los monstruos, un vaho de cálida respiración, un poco de suave vello en las garras y enseguida estabas dispuesto a amar y a atraer" (Nietzsche, 2006, p. 226), en clara antítesis con la actitud combativa y exterminadora frente a otros terribles dragones, aquí nuestro personaje se muestra poseído por una inmensa ternura hacia ellos, arrastrado por una sensación amorosa irresistible.

Frente a ese "monstruo" dormido y vertiginoso que es el mar y que infunde tal sentimiento de tristeza Zaratustra se ve tentado a consolarlo, a redimirlo de las pesadillas que parecen asediarlo, justo cuando acababa de decir: “ ¡Ay ese mar triste y negro a mis pies!, ¡Ay, esa grávida desazón nocturna! ¡Ay destino y mar! ¡Hacia vosotros tengo ahora que descender!", también resaltando ese ir hacia abajo que desde el inicio de la obra tiene tantos y tan profundos significados en la sicología de Zaratustra y en el sentido de sus viajes y correrías: "me encuentro ante mi montaña más alta y ante mi más larga caminata: por eso tengo que descender más bajo de lo que nunca descendí", haciendo eco de las conocidas frases herméticas que correlacionan interactivamente el arriba y el abajo.

Según había sido argumentado anteriormente, se sube para descender más bajo, y la caída más vertiginosa se corresponde con la superación de sí mismo y logro de la más alta meta. Por eso no es extraño que el sentimiento más bondadoso lo embargue ante la monstruosidad mareante del océano. En vez de atacar a la bestia gigante, como había sido el caso del super- dragón que enfrenta el león como segundo avatar o metamorfosis del espíritu, o el Estado como animalazo helado que debemos doblegar, o la energúmena presa del "super-hombre", en este caso la contradicción es irrisoria: Zaratustra quiere acariciarlo y acunarlo.

Inicialmente él mismo se ríe de este impulso algo ridículo, pero "entonces pensó en sus amigos abandonados -, y como si los hubiera ofendido con sus pensamientos, enojóse consigo mismo a causa de estos. Y pronto ocurrió que el que reía se puso a llorar. De cólera y de anhelo lloró Zaratustra amargamente" (Nietzsche, 2006, p. 226). Estamos en la transición al acápite titulado "De la visión y del enigma" y donde se va a manifestar el primer enigma del eterno retorno, ese "dragón adormilado" o intuición enloquecedora e inefable, suerte de acertijo recubierto de otros acertijos en una concatenación de creciente e insoportable incertidumbre, ante el que nuestro personaje queda como alelado y afantasmado.

Este desvanecimiento o incluso "difuminación" en los términos pictóricos que se han venido insinuando a partir de la poética visual de Francis Bacon, además 
del hundimiento en niveles de desolación insospechados para los marineros que finalmente descubren su presencia en el barco, corresponde a la pérdida de consciencia de Zaratustra una vez se embarca: "estuvo callado durante dos días, frío y sordo de tristeza, de modo que no respondía ni a las miradas ni a las preguntas" (Nietzsche, 2006, p. 227). Lo que ocurre entre tanto es la revelación más importante del libro, la seguidilla de visiones que culmina con la imagen del pastor mordiendo la cabeza de la serpiente que se ha introducido furtivamente en su garganta.

Pero tal epifanía solo es posible en un estado de "rapto", "arrebato" o "estado alterado de consciencia", como parte de una "difuminación de sí" comparable a la que experimenta la figura en la obra de Bacon, tal como decía Foucault de la anakhoresis que incluíamos iniciando estas reflexiones sobre la soledumbre: "La retirada, entendida en estas técnicas arcaicas de sí, es una manera determinada de apartarse, de ausentarse - pero de ausentarse in situ - del mundo dentro del cual estamos situados: en cierto modo, cortar el contacto con el mundo exterior" (Foucault, 2004, p. 60).

Solo que ahora es posible ampliar su significado y continuar la cita en esta paradójica dirección: "[se trata de] no experimentar ya las sensaciones, no agitarnos ya por todo lo que pasa a nuestro alrededor, actuar como si ya no viéramos, y efectivamente, no ver ya lo que está presente, ante nuestros ojos. Es una técnica, por decirlo así, de la ausencia visible. Siempre estamos ahí, visibles a la mirada de los otros. Pero estamos ausentes, en otra parte" (Foucault, 2004, p. 60).

Es de destacar que esa situación liminar y propicia es posible gracias al ejercicio o askesis de la soledad, ya que es gracias al prolongado entrenamiento en la soledumbre que Zaratustra puede lograr la proeza de estar en medio de sus semejantes sin estar del todo allí. Teniendo la visión, el acertijo y la provocación infinita que es la doctrina del eterno retorno, porque en la narración es después de este raro pasmo que Zaratustra les cuenta a los marineros lo que percibió en tal estado.

Practicante consumado el arte de la anakhoresis, del acecho de sí mismo, el arte de desaparecer o difuminarse sin acabar nunca de desaparecer, es la severidad y el extremo rigor de esta práctica la que lleva a Zaratustra a este logro, no como se domina un conocimiento científico o una ley o fórmula abstracta, sino como se sufre y se aprende a vivir un destino trágico, grandioso en su temible tragedia. Lo anterior emparenta este vértigo con el ánimo, que ya Nietzsche describía en otra carta de esta misma época, a Köselitz el 10 de mayo de 1883: "Pero sustancialmente sigo aferrado a la opinión de que me espera una profunda y severa soledad, más profunda y severa que nunca" (Nietzsche, 2010, p. 357), y también como dice en el Zaratustra de su "última" y más terrible soledad.

En verdad aquí aparece la soledad como todo un personaje, alguien que aguardará por él, quizá para prodigarle nuevas y más extrañas revelaciones, pero también para asfixiarlo y enrarecerlo aún más, como la figura de Bacon, incitándolo a traspasar 
un umbral desconocido, a tener la experiencia de la desolación más completa, en medio de marineros o quienes sea, rodeado de la severidad y grandeza de su propia inabarcable tarea.

En una última sección, será abordado el escabroso y desolador tema de la escritura de la historia, en el que las anteriores intuiciones traspasarán la escritura sobre la soledad de Nietzsche y de su personaje Zaratustra, nuevamente resonando con algunas pinturas de Bacon, el motivo de la melancolía y la aparición siempre indecisa y siempre indudable del fantasma en cualquier aproximación a los acontecimientos del "pasado".

\section{3. EL FANTASMA DEL SOLITARIO Y LA HISTORIOGRAFÍA}

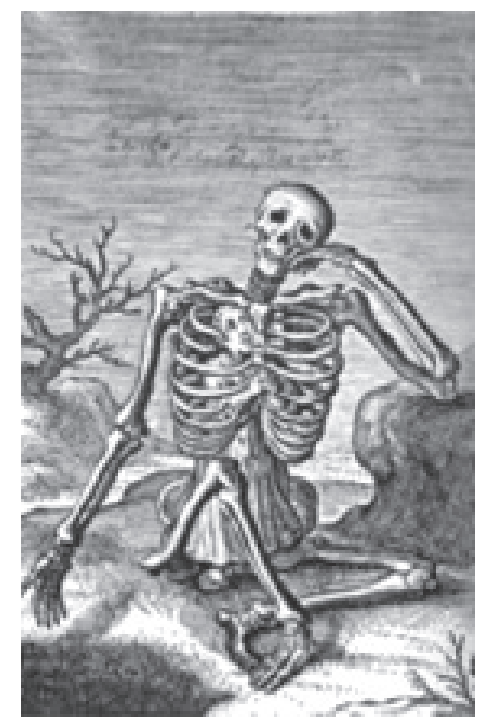

Habitante indeciso de su muerte en vida, alegoría alquímica. Pia Desideria, Herman Hugo, Amberes, 1624.

Mas la desproporción entre la grandeza de mi tarea y la pequeñez de mis contemporáneos se ha puesto de manifiesto en el hecho de que ni me han oído ni tampoco me han visto siquiera. (Nietzsche, 1995, p. 15)

Como a un fantasma, como a una especie muerto-vivo tratan sus contemporáneos a Nietzsche, él vive entre ellos pero como si no viviera entre ellos. Esta situación liminar que ya fue abordada a propósito de la anakhoresis in situ de Zaratustra al momento de tener la revelación en forma de adivinanza del eterno retorno, se reviste aquí de otro sentido, ese estar sin estar decantado de la experiencia de la soledad, ese ausentarse o devenir imperceptible, aún en medio de sus congéneres es visto aquí como una tortura, como una situación inaceptable. La primera inaccesibilidad de Zaratustra era un signo 
de su fortaleza, de su impenetrabilidad, de la gran exigencia de llegar a compartir incluso su "pensamiento abismal"; pero aquí, en las primeras líneas de Ecce Homo, Nietzsche se queja de esa suerte de muerte en vida causada por la ignorancia acerca de su obra.

Como en el borrador de 1884 citado más arriba cuando se trataba de rechazar la compañía de "exaltados mediocres": "Querido señor Levi. Quién sabe si se acordará usted aún de mí. Pues soy un ermitaño, y si yo mismo he olvidado a medio mundo, con razón al menos tres cuartas partes del mundo (o más) se habrá olvidado de mí" (Nietzsche, 2010, p. 515). Ya en Ecce Homo, como autobiografía e introspección de sí y de sus obras, resulta insoportable ese "olvido" del mundo sobre sus libros y sobre sí mismo que enérgicamente denuncia el autor del Zaratustra.

No es posible perder de vista la alegoría alquímica que ilustra esta situación: en un yermo, bajo un indefinido cielo oprimente, rodeado de maleza inhóspita o marchita, en medio de una gran desolación, un suplicante - se infiere por la posición de sus manos- se halla literalmente "encerrado" por el símbolo de la muerte, atrapado en la cárcel de su propia osamenta luego de perder la vida, quizá. La desproporción en el tamaño del esqueleto ayuda a crear la sensación de lo inverosímil, su postura no es la del orante, sino la de la melancolía, el brazo que sostiene la cabeza -el cráneo óseo- como de mala gana, expresando aburrimiento o "tedio vital".

Como en el grabado clásico de Durero del mismo título, el melancólico vive una suerte de aflicción y pesadumbre infinita, casi como un "alma en pena" el melancólico padece una agonía inacabable, habitando el umbral entre muerte y vida, desinteresado de una manera absoluta por los asuntos cotidianos, entregado a un duelo inasible e infinitivo, tal es el estatus de estas figuras aburridora y mortalmente cansadas de la vida, que no encuentran un horizonte y se hallan divagantes sin metas y sin propósito.

Se sabe que la Melancolía o acedia era considerada un pecado capital en la Edad Media, el "demonio del mediodía" se cebaba en estos espíritus magistralmente retratados en el personaje Roderick Usher, del magnífico relato "The fall of the house of Usher” de Edgar Allan Poe. En él se respira esta atmósfera de descomposición y pesadumbre e incluso llega a ser visible como un halo espectral que aureola la casa y que acaba determinando su raro y poético colapso.

La melancolía como padecimiento nervioso que hiper-agudiza los sentidos y las fibras sensibles. Es muy significativo también que en ese relato la hermana del protagonista sea "enterrada vida" por error y por efecto de la catalepsia que la aqueja. Así también con relación al mago justo en el pasaje llamado "La canción de la melancolía” en la cuarta parte del Zaratustra, quien induce esa flojedad melancólica en los hombres superiores reunidos en su caverna, aprovechando que Zaratustra ha salido a respirar aire puro lejos de la compañía de estos enrarecidos y propensos a la tristeza hombres superiores, su canción los ablanda y los sume en esa contemplación meditativa y bella pero paralizante y siempre decepcionante del sentimiento melancólico (Nietzsche, 2006, pp. 402-408). 
También con referencia al "espíritu de la pesadez", ese topo cojitranco e impertinente tiene mucho que ver con este estado de ánimo, un nihilismo sin fronteras, un cáncer de desolación que lo afecta todo, una pululación enfermiza y atosigante de desánimo, entre la pereza y la atonía total, hoy en día se hablaría de síntomas de depresión crónica en estos casos, o incluso de la fase depresiva de un cuadro de temperamento bipolar.

Muchos historiadores del fenómeno, desde Aristóteles, han asociado este mal con la genialidad y la tendencia artística, un tanto como Zweig se refería a Hölderlin y Kleist, pero sobre todo a Nietzsche en su estudio La lucha con el demonio del que ya tuvimos ocasión de hablar. Se trataría de seres "marcados con fuego", sometidos a la influencia del planeta Saturno, sumidos permanentemente en esa fase de opus nigrum o nigredo de la obra alquímica, destinados sin esperanza a un descontento ontológico, nostálgicos de un indefinible abismo.

Sigmund Freud sostendrá que en estos pacientes el trabajo de duelo no acaba de realizarse nunca y el sujeto se convierte a sí mismo en objeto de recriminación y rechazo, el objeto perdido se afantasma y la formación psíquica llamada "yo" queda atrapada en un permanente y agobiante reproche moral, como si los asqueara la misma estructura de su personalidad, este espesamiento opresivo salido de todo control. Derrida también se refiere al fenómeno en la parte II de La bestia y el soberano:

La melancolía no es la nostalgia, aunque entre estos dos afectos haya una afinidad, una analogía, que se debe por lo menos a que estos dos padecimientos padecen una falta, una privación, incluso un duelo. Heidegger (de quien muchos testimonios atestiguan que él mismo era de temperamento bastante melancólico, algunos dicen "depresivo", como todos nosotros, en el fondo, que nos dedicamos a filosofar ¿verdad?) quiere sostener que la filosofía es melancólica, fundamentalmente, esencialmente melancólica, no en su contenido — dice - sino en su forma. (Derrida, 2011, p. 152)

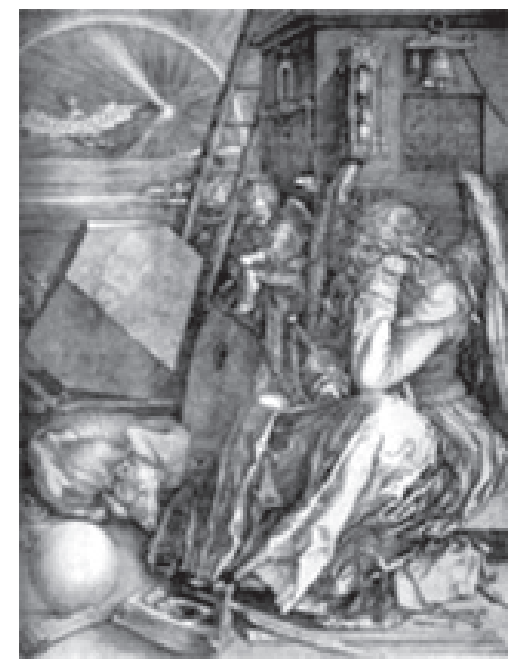

A. Durero, La melancolía I, 1514 
Este pasaje de Derrida al seguir el rastro de M. Heidegger y su seminario de 19291930 titulado Die Grundbegriffe der Metaphysik. Welt - Endlichkeit - Einsamkeit ("Los conceptos fundamentales de la metafísica: Mundo, Finitud y Soledad") adjudica ese tipo de ánimo a la actividad filosófica tout court.

En una discusión sobre las tonalidades básicas del filosofar, a partir del filósofo de Friburgo, Derrida hace las anteriores aseveraciones, citadas aquí para relacionarlas con la propensión que las personas de talento excepcional tienen a ser melancólicos, especialmente Nietzsche y su álter ego Zaratustra, quien libró una batalla enorme contra ese monstruo del debilitamiento y la ausencia de motivos para vivir, ese ángel o daimon maligno, decíamos, graficado en el "espíritu de la pesadez" y considerado su archi-enemigo, proto-enemigo, oponente radical o enemigo visceral.

Ahora bien, podrían conectarse estas ideas con la frase que abre este apartado y que era visualizada a través de ese suplicante aislado o insularizado por los huesos enormes y desmedidos de un esqueleto en la clásica postura de sumo aburrimiento y fastidio consustancial; así como la ya obligada imagen de Durero del ángel melancólico en su laboratorio, rodeado de los símbolos de esta clase de modo existencial, con el atardecer frente a él, momento también privilegiado para ser asaltado por este "espíritu [Geist]" o "duende", allí donde la Untergang o "hundimiento en su ocaso" de Zaratustra tiene todo que ver con este sentimiento de asfixia vital sin remedio.

De la asociación entre Nietzsche y la melancolía - y que resulta tan prolífica si se examina el contenido y tono de su correspondencia (y no solo de este periodo)-, interesa ese estado umbrátil e intermedio del melancólico como muerto en vida, la naturaleza espectral que se asume, incluso desde el punto de vista físico respecto a los síntomas de esta decadencia y abulia trepidante, pero sobre todo en cuanto el mismo Nietzsche, como un fantasma sentía que los vivos no lo percibían, en el ambiente cultural que lo rodeaba se paseaba como un alma en pena, como una aparición condenada a vagar sin sentido. Continúa el autor en Ecce Homo:

Yo vivo de mi propio crédito; ¿acaso es un mero prejuicio que yo vivo?... Me basta hablar con cualquier "persona culta" de las que en verano vienen a la Alta Engadina para convencerme de que yo no vivo. (Nietzsche, 1995, p. 15)

Si el hecho de vivir se torna en un mero prejuicio, ¿qué implica ello para el que escribe esas atormentadas frases?, ¿qué implica para un ejercicio hermenéutico como el que se intenta en este libro? Es decir, si no se tiene la certeza de vivir como tal sino solo un prejuicio y, además, si al preguntar a las "personas cultas" en su momento nos convenceríamos de que Nietzsche no vive, ¿quién hace estas denuncias?, ¿un muerto viviente?, ¿alguien atrapado inconsistentemente en planos de realidad pertenecientes al mundo de los vivos y al de los muertos?, ¿simultáneamente fallecido y en movimiento?, ¿qué esfera de la vida o de la negación de la vida es esa? 
Derrida des-construyendo estas mismas frases de Ecce Homo, en una conferencia dictada en 1976 y publicada con el título "Otobiografías, la enseñanza de Nietzsche y la política del nombre propio”, ha dicho:

su propia identidad, la que él pretende declarar y que no tiene nada que ver $-\mathrm{a}$ tal punto les resulta desproporcionada - con la que sus contemporáneos conocen por ese nombre, o mejor dicho su homónimo. Friedrich Nietzsche, esa identidad que reivindica, no la debe a un contrato con ellos, sus contemporáneos. La recibe del contrato inaudito que ha suscripto con su propia persona (Derrida, 2009, p. 36).

De allí la extraña expresión "Yo vivo de mi propio crédito", "crédito" que aquí tomamos en su acepción de "dar crédito" como creencia, es decir, solo Nietzsche cree aún que está vivo, los demás no comparten esa creencia, para los demás él ya abandonó este mundo o nunca estuvo en él, su desconocimiento del autor de Así habló Zaratustra es total. Pero acaso ¿esa no es la posición clásica del fantasma?, aquel renuente a dejar el mundo de los vivos, aquella sombra o espectro que se niega a dejar de creer que vive, que persiste quizá ciega o en todo caso terca o torpemente en la vida, que asedia la vida, a los vivos desde su morada espectral, desde su no- lugar entre muerte y vida:

Nietzsche puede escribir que su vida no es acaso más que un prejuicio. Un prejuicio, la vida, o mejor que la vida, mi vida, lo "que yo vivo", el "yo vivo" en presente. Es un pre-juicio, una sentencia, un fallo precipitado, una anticipación arriesgada; podrá verse en el momento en que el portador del nombre, aquel a quien llamamos por prejuicio "un viviente", esté muerto. (Derrida, 2009, p. 37)

Se interpola aquí el motivo que enlazará el tema del muerto vivo, la "supervivencia" por la escritura, el carácter póstumo de la obra de Nietzsche, la soledad del muerto o del espectro, su paradójico aislamiento, con unas reflexiones sobre la narrativa y la escritura histórica en particular:

En las sesiones precedentes, en más de una ocasión, he recurrido a la palabra, si no al concepto, de fantasma, en particular para figurar o configurar lo contradictorio, lo inconcebible o lo impensable, lo que denominamos, siguiendo siempre las huellas de Robinson Crusoe, el "morir estando vivo", el morir estando vivo que infundía tanto miedo a Robinson, ese estado en el que el muerto está lo suficientemente vivo para ver y saber que va a morir, para vivir su propia muerte, para durar, perdurar y soportar el momento de su muerte, para estar presente en su muerte y más allá, sin dejar no obstante de morir, para sobrevivir a su muerte al tiempo que se muere efectivamente. (Derrida, 2011, pp. 194-195) 


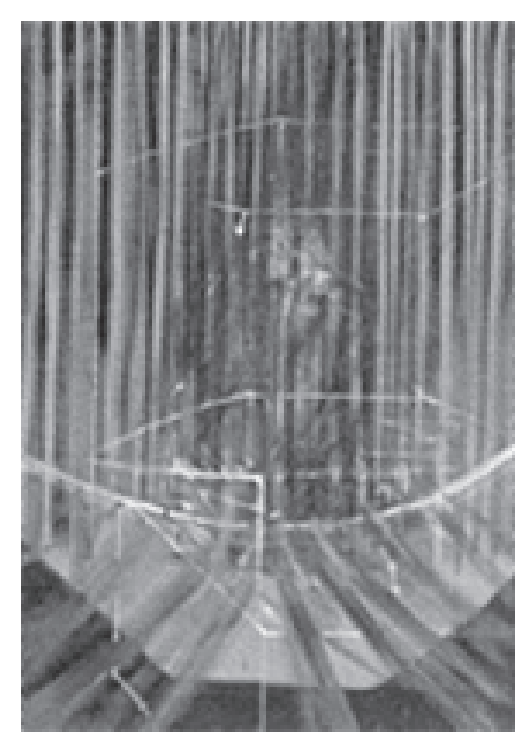

Fantasma aislado.

Francis Bacon, Sin título (Figura), 1950-1951

El fantasma es la narración autobiográfica, como en el caso de Ecce Homo, pero también con respecto a Así habló Zaratustra y en general a toda la obra de Nietzsche, ella lo "sobrevive", vive más que quien la ha escrito, el relato habla de un muerto como si estuviera vivo, especialmente a quienes lo leen después de muerto su autor.

Esta sería una característica de toda ficción, de toda escritura en últimas: "Lo mismo, por lo demás, que cualquier huella, en el sentido que le doy a esta palabra y a este concepto, un libro es un muerto viviente, enterrado vivo y engullido vivo" (Derrida, 2011, p. 174). Ese fantasma apenas lo vemos en este cuadro de Francis Bacon, sus contornos nuevamente se difuminan, se transparentan, se escapan como humo; ya había sido vista esa rara y vaporosa "desaparición" en la imagen del último momento que propuesto en el recorrido de la soledad de Zaratustra.

Pero aquí el "espectro" se halla aislado, como por el artificio de la escritura el espectro del propio Nietzsche está contenido y desbordado en sus escritos, al igual que en esa imagen que explora los límites mismos de lo visible, la obra de Nietzsche es como ese receptáculo anamórfico o geométrico que lucha por "contener" la figura, por delimitarla para hacerla visible.

El dispositivo o prótesis técnica que es la escritura también intenta, acaso fallidamente, acaso sin saber nunca si lo logra, "aislar" a su autor, aquí representado en esa suerte de emanación, de vapor entre translúcido y siniestramente opaco; aquel del que nunca se sabrá a ciencia cierta su identidad, como ocurría con los anteriores retratos de Bacon (Tres Estudios de cabeza humana de 1953). 
Las facciones se han hundido monstruosamente en una incertidumbre de muy difícil caracterización, de esta imagen interesa especialmente el mecanismo para generar la irrealidad que la constituye, la creación de un "aura" unheimliche, esa familiar desfamiliarización a la que Freud dedicara un famoso ensayo a propósito de la obra fantástica de E. T. A. Hoffman. Más que ver, lo que apenas se atisba o intuye en el cuadro son esos misteriosos trazos verticales que se han transformado de la anterior imagen del desnudo atravesando la cortina, en una ondulación de la perspectiva misma, Luigi Ficacci dice al respecto:

Los trazos de la cortina que, en su evolución, habían experimentado una complicación de la propia identidad hasta convertirse en puros momentos gestuales y enunciar nuevas tipologías de la forma, ahora ya son totalmente independientes de su origen como objeto. Aquí aparecen como una especie de lluvia cromática que empaña y descolora el aspecto del cuerpo hasta marcarlo de un modo que resulta casi una cicatriz de la existencia y del trágico recorrido que ha transformado el rastro de la existencia en imagen. (Ficacci, 2010, p. 38)

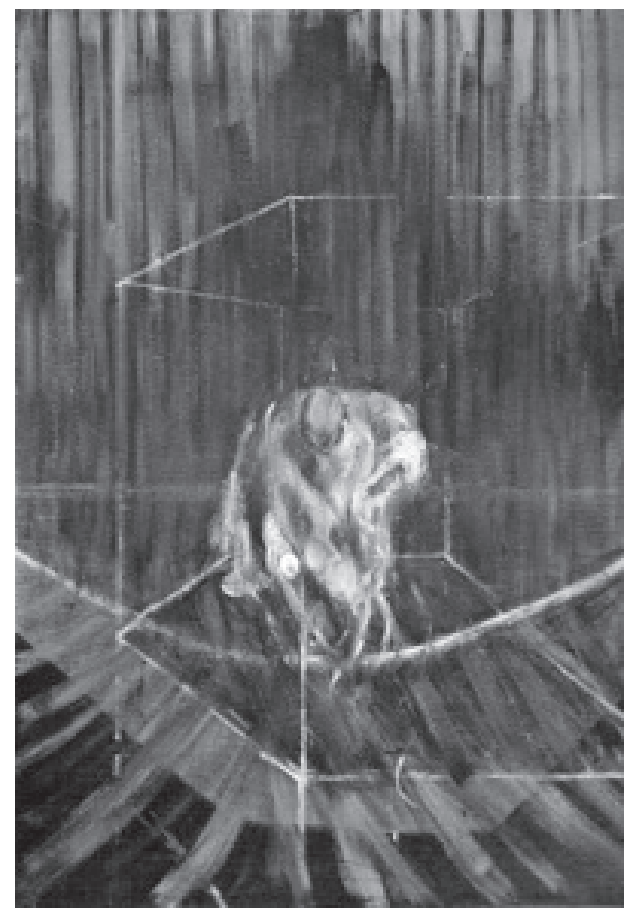

Francis Bacon, sin título (desnudo agachado), 1950-1951

Se está en presencia, en la emborronada presencia del proceso de constitución de la imagen misma, la génesis del acto de ver algo, proceso que se esquiva y se muestra de una forma brutal y desnuda en estas pinturas. Se trata de la imagen del fantasma si se siguen las pistas adelantadas hasta ahora-. La dificultad para circunscribirlo y 
saber de una vez por todas de lo que se está hablando, la sombra huidiza de Nietzsche que ya "en vida" creía no estar en vida, según se lee en las primeras líneas de Ecce Homo, en el sentido que le da Derrida a la novela Robinson Crusoe también.

La aprensión del protagonista de ser devorado o enterrado vivo en la isla a la que llega luego del naufragio, ese es el miedo supremo, el terror máximo, el ser presa del salvajismo de los caníbales. Ese temor es su fantasma, la imagen del momento de perder sin perder la vida, "sobrevivir" a la propia muerte o imaginar que se sobrevive: para la extraña "lógica" del fantasma ambas afirmaciones se equiparan.

Para seguir respirando el aire que se desprende de estos cuadros de Bacon, se sostiene con Luigi Ficacci, que esa "cortina" o ese "efecto de cortina" es clave en el intento de explicitar el encuadramiento del fantasma, esos cuerpos cuya carnalidad se difumina y que aparecen casi flotantes a la vez que innegablemente materiales. La cortina como la escritura misma, ese "efecto de visión" que impide ver la figura -la escritura no es la encarnación de quien escribe, ella no agota el devenir vital del escritor - en el acto de hacerla visible — solo "se ve" a Nietzsche a través del espesor y la opacidad semi-transparente de sus libros, fragmentos y correspondencia-.

En el punto de máxima transfiguración esta lluvia cromática aporta, con una profundidad traumática, esa sensación de telón diáfano, de travesías luminiscentes, que convertía las primeras apariciones de la cortina, en algo más que un objeto. Se trata más bien de la expresión de un estado indefinido de la consciencia, una crisálida capaz de esparcir incertidumbre y duda sobre cada apariencia visible de la pintura. Es como una especie de emanación psíquica que se concentraría en un objeto mediante un proceso sensitivo y obsesivo. (Ficacci, 2010, p. 38)

Sin entrar de fondo en el espinoso e intangible asunto de la "emanación psíquica" y más en un texto referido a los fantasmas y las apariciones obsesivas, como lo era la trascendencia o el afán de posteridad para Nietzsche, las palabras de este crítico de arte resuenan acerca de ese "estado indefinido de la consciencia" que padece el fantasma, no es solo la falta de vida lo que lo obsesiona, sino la falta de criterios para determinar si vive o no vive, en suma.

Una tercera imagen de Bacon resulta pertinente, se trata de un estudio sobre un famoso retrato del papa Inocencio X del pintor Diego Velásquez, aquí no solo se retrata un muerto, sino que el cuadro es sobre otro cuadro de un pintor también muerto; de nuevo se aprecia esa cortina casi como simbolizando un tenebroso grito post mórtem, y más debido a las fauces abiertas del retratado. El cuadro se balancea entre una alucinación, el vaho en una cortina de baño, la vaga impresión de haber "visto algo" y la certeza de la figura allí atrapada y allí mismo fugándose: 


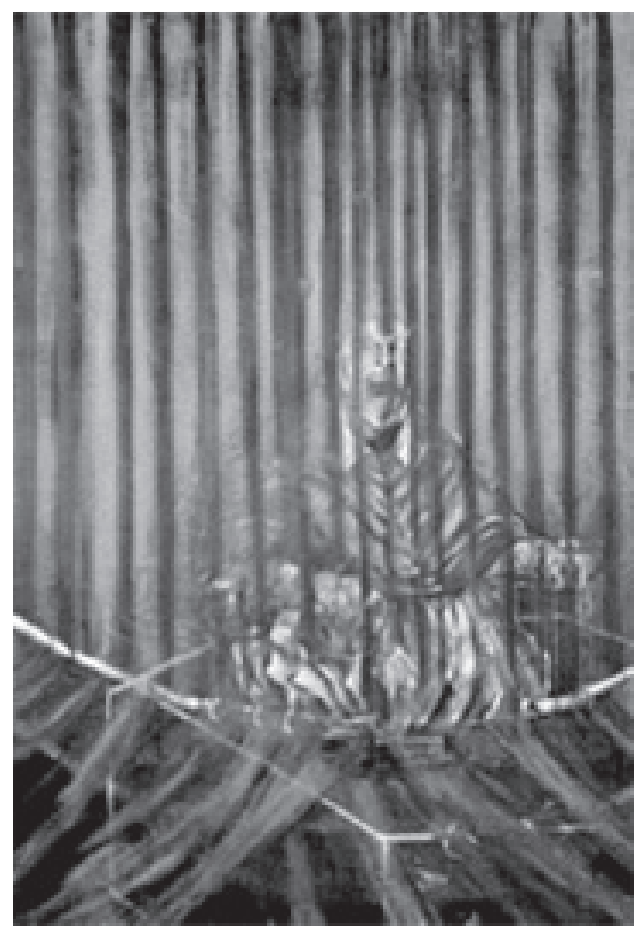

Francis Bacon, Estudio de Velásquez, 1950

Este fantasma allí momentáneamente retenido es el relato mismo en sus condiciones de posibilidad, en su imposibilidad misma, la dificultad de situarlo en el "orden de los acontecimientos" instaurado por el relato (siempre lineal, siempre amenazante para la aparición que rebasa ese aplanamiento).

El muerto con esa mueca paródica y meta-irónica interpela al observador tanto como las frases de Nietzsche que abren este acápite, desde esa extraña "lógica del fantasma":

Esta lógica del fantasma resiste, disloca y desafía el lógos y la lógica en todas sus traducciones y en todas sus figuras, ya se trate del lógos como razón y como lógica de la no- contradicción y del tercero excluido, del sí o no, del sí y del no, del bien lo bien decidibles, ya se trate del lógos como palabra o ya se trate del lógos como compilación o potencia de reunión (Derrida, 2011, pp. 234-235).

De allí la relación con la imagen inaudita de "presenciar" o "sobrevivir a la propia muerte", pero, ¿qué es esta supervivencia?, ¿de qué se trata con esa "sobrevivencia"35 de la ficción narrativa del personaje?: "Ahora bien, esa pervivencia gracias a la cual el libro que lleva ese título [Robinson Crusoe] ha llegado hasta nosotros, ha sido leído y será leído,

35 "Eso es asimismo la finitud, la fortuna y la amenaza de la finitud, esa alianza de lo muerto y lo vivo. Esa finitud, diría yo, es supervivencia" (Derrida, 2011, p. 174). 
interpretado, enseñado, salvado, traducido, reimpreso, ilustrado, filmado, mantenido en vida por millones de herederos, esa pervivencia es en efecto la de un muerto viviente" (Derrida, 2011, p. 174, subrayado añadido); un muerto que aún aparece y asusta gracias al entramado de signos de su escritura, estatus de muerto en vida de Zaratustra como ficción del recorrido de peripecias que leemos en sus "discursos", ilusión de su palabra como afantasmada al plasmarla Nietzsche de la manera como lo hizo.

Así como se habla de la "voz" de los muertos recogida por el historiador, reconstruida a través de documentos u otros signos, así Derrida se interroga acerca de la sobrevivencia a la propia muerte cuando es pensada por aquél que ya no vivirá ese momento. El relato de la propia muerte como si el muerto pudiera ver y estudiar las reacciones de sus allegados y personas queridas, esa es la sobrevivencia que se cuestiona especialmente en un relato denominado histórico y autorizado para servir de referencia sobre los acontecimientos del pasado.

Y más si este relato se halla ligado a una temporalidad no fantasmal, es decir, una temporalidad que excluye o no ve la aparición atemporal e intempestiva del espectro, ese momento que trastoca el orden temporal definido en la narrativa. Tanto como el fantasma de Nietzsche o de Zaratustra no como "emanación" de su "alma" aun circundándonos o asustándonos, sino el fantasma como imposibilidad de situar en un estricto orden único la figura de su autor y sus personajes. El fantasma sería esa indecisión, la que acosaba a Nietzsche en los últimos años de su vida y que expresa categóricamente en el Ecce Homo, la duda sobre su existencia y la duda aún mayor sobre sus lectores futuros o el destino de sus textos, esa indecisión es y no es nunca el fantasma.

Como los seres tenuemente encasillados en los trazos de Bacon, están pero no están allí, su consistencia no es definitiva, como ilusiones ópticas o contornos solo vistos con el rabillo del ojo, o como las imágenes de los sueños, de las cuales nunca se tendrá plena seguridad de su forma o de su significado, lo que asedia es esa irresolución, la "materialidad" del acontecimiento histórico en suma.

Lo que para el historiador son sus fuentes pero a partir de las cuales nunca podrá hacer una reconstrucción exhaustiva o siquiera aproximada según algún criterio de "objetividad" o "neutralidad" científica. La evanescencia de las imágenes del pasado, sobreviviendo gracias al fantasma, la memoria como fantasma, sobreviviendo también y paradójicamente a pesar del fantasma, como esa cortina que permite e impide la contemplación tranquila de los cuerpos de Francis Bacon, una mancha constitutivamente anamórfica, distorsionante, una desfiguración ineliminable, suerte de presentación del mismo punto ciego de la mirada, en su miseria pero también en la espacialidad que le es propia.

Volviendo al asunto de la supervivencia en el seminario La bestia y el soberano II, sostiene Derrida:

Una supervivencia que no está más viva ni, por lo demás, menos viva que la vida, ni más ni menos muerta que la muerte, una supervivencia que no se pliega ni al comparativo 
ni al superlativo, una supervivencia o un sobrevivir, supervivencia cuyo super carece de superioridad, de altura, de altitud o alteza, por consiguiente de supremacía y de soberanía. No añade un plus a la vida, de la misma manera que tampoco se lo resta, de la misma manera que no se lo resta a la muerte ineludible o que no atenúa su rigor, su necesidad, lo que podría denominarse, sin pensar todavía en el cadáver ni en su rigidez erigida, el rigor mortis, si quieren ustedes. No, la supervivencia de la que hablo es otra cosa distinta de la vida o de la muerte; es un fondo sin fondo a partir del cual se recortan, se identifican, se oponen lo que creemos poder identificar con el nombre de muerte o del morir (Tod, Sterben). (Derrida, 2011, pp. 174-175)

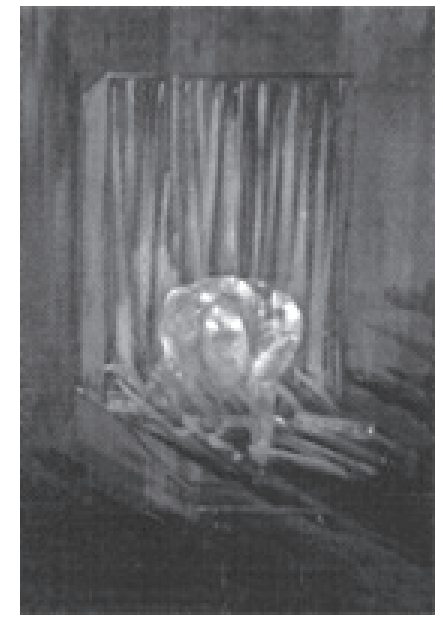

Bacon, Estudio de desnudo, 1951

Así la supervivencia del espectro Nietzsche, la aparición que es la historia de su vida: ¿QQué historia? ¿Qué historias? ¿Cómo poner de acuerdo lo fantasmático o lo fantástico con lo narrativo, con la ficción narrativa, incluso con la literatura fantástica, con historias que conceden tiempo y porvenir al muerto?" (Derrida, 2011, p. 210). Sobre todo cuando se sigue explorando esta "lógica fantasmática" y es posible darse cuenta de que el hecho de ser Así habló Zaratustra una "ficción" como Robinson Crusoe, o como tantos relatos literarios al respecto y de los cuales un ejemplo precioso son los cuentos de Edgar Allan Poe, introduce de lleno e indecisamente al fantasma como temporalidad y como personaje textual.

Justo allí donde los relatos "ficticios" crean a los personajes, como en últimas hace toda autobiografía, en particular dado el estilo poético del opus magna de Nietzsche, el cual no sería una debilidad o un capricho estilístico de su autor, sino que respecto a esta temática del fantasma sería un entorno sumamente favorable y acogedor, hospitalario en sumo grado, debido a la naturaleza de la obra "así llamada literaria”, "así llamada fantástica”:

Por eso en todos los temas de los que tratamos aquí - la soberanía, el animal, el muerto viviente, el enterrado vivo, etc. lo espectral y lo póstumo- [Nietzsche 
como muerto en vida, como enterrado vivo], pues bien, el sueño, lo onírico, la ficción, la ficción así llamada literaria, la literatura así llamada fantástica serán siempre menos inapropiados, más pertinentes, si ustedes prefieren, que la autoridad de la vigilia, que la vigilancia del ego y la conciencia del discurso así llamado filosófico. (Derrida, 2011, p. 235)

Lo anterior como punto de partida en una refiguración de la distinción que desde lo epistemológico escinde la narrativa histórica de la narrativa "así llamada de ficción", separándolas con la certeza de una taxonomía científica hostil al espectro, al espacio ubicuo e inubicable de su epifanía, pero también a la temporalidad intensiva que lo caracteriza. Sobre ello continúa Derrida en este tono: "Por todas partes donde puedo tener lugar, hay también un tiempo dado, y el fantasma o el sueño diurno puede hacer 'como si', contarse una historia de un 'como si', justamente como si la historia no hubiese terminado [haber muerto]" (Derrida, 2011, p. 210).

La expuesta es una paradoja tremenda que cuestiona los límites biológicos y filosóficos atribuidos a la muerte como algo inexorable, porque definitiva e infinitivamente penetrar en los dominios del muerto vivo implica un desafío a esos marcadores temporales tenidos por absolutos. Una reconsideración, desde las voces de Nietzsche y Zaratustra, de la plantilla de temporalización que establece como inamovibles ciertas demarcaciones, particularmente la manera como el historiador usa esos mapas pre-conceptuales o marcos lógicos para darle consistencia al relato.

Asumiendo al relato mismo como fantasma, se diría si la historiografía derivada de la epistemología de la modernidad no pretendiera exorcizar (de manera sospechosa y siempre sintomática) al fantasma, excluyendo la ficción hiper- real de su presencia de la imagen consolidada de historia, allí donde el significado usualmente otorgado a los fantasmas, no pasa de ser una rareza psicologizada, un episodio en la historia de las supersticiones o de las creencias "subjetivas", olvidando o simulando olvidar que el fantasma está en el origen de cualquier aproximación al pasado, el espectro es el relato y la indecisión del relato, su "fidelidad" a los "hechos" y la deformación perspectiva siempre presente en cualquier narración histórica.

Se terminará haciendo alusión a un extraordinariamente pertinente poema de Nietzsche, inicialmente enviado a Heinrich von Stein a Berlín a finales de noviembre de 1884 con el título "añoranza del solitario", pero posteriormente aumentado e incluido como épodo al final de "Más allá del bien y del mal" con el título "desde altas montañas". Se enlazan allí los motivos de la soledad, la melancolía, la nostalgia, el abandono, la autosuperación creadora, la amistad y la conversión en fantasma (incluso la génesis siempre "espectral" de la figura de Zaratustra):

¿Yo busqué donde más cortante sopla el viento?

¿Aprendí a habitar

donde nadie habita, en las yermas zonas del oso polar,

olvidé al hombre y a Dios, maldición y rezo? 
¿Me he vuelto fantasma que anda sobre neveros?

¡Viejos amigos, mirad! ¡Si estáis demudados,

llenos de amor y alarma!

¡No, id; no os enojéis! Aquí vosotros no tendríais casa:

en el reino extremo del hielo y del peñasco,

aquí hay que ser cazador, de gamuza hermano.

(Nietzsche, 2008b, pp. 93-95) ${ }^{36 .}$

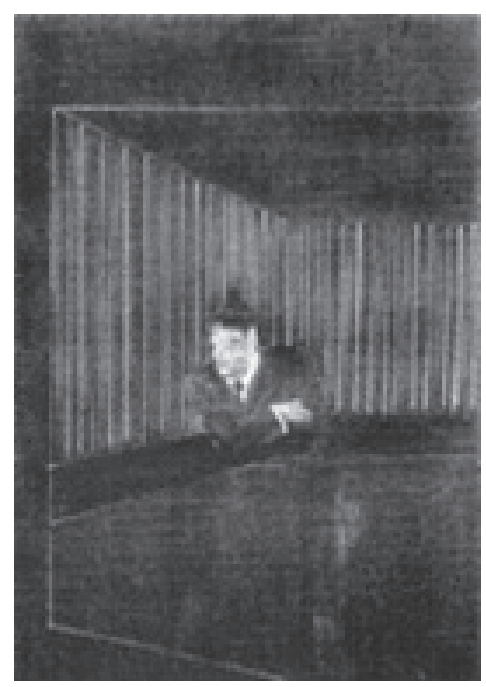

Francis Bacon, Hombre en Azul I, 1954

36 El poema completo es el siguiente: "DESDE ALTAS MONTAÑAS

¡Mediodía de la vida! ¡Solemne tiempo!

¡Oh jardín estival!

Inquieta dicha de estar de pie y otear y aguardar:

día y noche espero a los amigos dispuesto,

¿dónde paráis, amigos? ¡Venid, ya es el momento!

$¿$ Es que hoy el gris del glaciar no se ha adornado con rosas por vosotros? [...]

[...]

¿Me he convertido en otro? ¿Y a mí mismo ajeno? ¿Zafado de mí mismo?

¿Un luchador que hartas veces a sí mismo se ha vencido? $¿ Q$ Que a su propia fuerza hartas veces se ha opuesto, por su propia victoria lastimado y preso?

[...]

Ya no son amigos, son - ¿y cómo les llamo?-

solo espectros de amigos,

que aún llaman de noche a mi corazón y a mis postigos, me miran y dicen: “ ¿no lo fuimos acaso?”.

¡Oh, palabra mustia, que a rosas olió antaño!

¡Oh anhelo de juventud, malentendido!

A quienes yo anhelaba,

a quienes transformados, conformes a mí imaginaba, el envejecer, lejos los ha retenido:

solo quien se transforma es conforme a mí mismo.

[...]

Acaba este canto; en la boca el dulce grito

del vivo anhelo expira:

un mago fue quien lo hizo, el amigo de la hora precisa, el del mediodía, entonces uno dos se hizo...

Ya celebramos la fiesta de fiestas, ciertos de victorias conjuntas:

¡Arribó el huésped de huéspedes, el amigo Zaratustra! Ya ríe el mundo, se rasga el telón horrendo, la boda entre luz y tinieblas llega a tiempo..." (Nietzsche, 2008b, pp. 93-95) 


\section{Excurso 1. Aión, cuestión de tiempo (El sueño empieza cuando el tiempo se detiene)}

Ahí nomacito, sobre el oleaje siempre indeciso y siempre justo de la Huachuma ${ }^{37}$, el tiempo que dura su efecto, sin límite entre dentro y fuera de la chuma, recuerda que "no tiene fin el sueño ni comienzo la vigilia", danzando en ese intervalo, ante la aurora tenue, la aurora sola, consciencia intranquila, tranquilita ahí, divagando las formas para retejer la urdimbre del secreto que a veces llamas tu mundo, otras tu misma consciencia, y las más dizque "régimen de la temporalidad", ahí no más, parafernalia de ese instante de "pura y silenciosa ausencia de temporalidad", ese es el pasmo de Zaratustra ante su pensamiento abismal.

El terror de Borges al Aleph: "sentí vértigo y lloré", dice en ese trance que pasa a cada momento, que es cada momento pasando y no pudiendo jamás de acabar pasando, pasando y no pasando al siguiente, bailando la desplegada ultra-condensación del tiempo de los enigmas, toda la noche al menos, jugándote nuevas cartas, te va la vida en este momento, pretendiendo urdir de otra forma el armadijo secreto que a veces llamas "realidad", ahí está bueno, tesitura inorgánica, ambición de ver con otros ojos lo que solo existe en el parpadeo.

Dizque para congelar el flujo de los acontecimientos ${ }^{38}$, tesitura energúmena, voces cuando recuerdan que hablan, que pueden seguir hablando, pero lo hacen siempre distinto y por eso se olvidan que el tiempo estaba pausado, era la pausa misma, la fascinación del instante por detenerse, no poder nunca detenerse y en ese traspiés dizque fraguar un mundo, en ese momento tan solo, decir que lo está tejiendo, sobre el oleaje de la Huachuma, a veces ondulante y otras simplemente extasiado.

Ahí nomacito, dormitando haberse dormido o pensando que podía haberse dormido, consciencia que se despierta, dándose cuenta del acto de darse cuenta, de recordar siempre eso, pero qué es eso, ajetreo imaginal, escalofrío en el gesto que pinta, que habla que pinta cuando nunca sabría, escribiendo despacio, danzando de valentía el absurdo, el sinsentido del tiempo, dizque su propia consciencia,

37 Trichocereus pachanoi. Cactus sagrado andino, entre sus principios activos está la mezcalina.

38 Del libro de Ann Marlowe How to Stop Time. Heroin from A to Z, pasando por Momo de Michael Ende o los protocolos de experiencia de Carlos Castaneda (especialmente Las enseñanzas de Don Juan) o el infaltable Milagro secreto del mismo Borges, la imagen del extremo ralentí temporal (cf. El llamado Bullet time cinematográfico inaugurado por las técnicas de cámara y edición digital en Matrix de los hermanos Wachowsky y ya convertido en una convención del género) confundido con su detención halla una expresión privilegiada en el film de 2012 Dredd (DNA films, IM Global, Reliance Entertainment) dirigido por Pete Travis (basada en el cómic Judge Dredd, 2000AD, 1977-99), en la que percibimos la mutación temporal generada con la ingestión de la droga "Slow-Mo". 
insinuación de sus esplendores, sustos súbitos, un pasmo de tan repetido indistinto, conjurando de nombres haber olvidado su nombre, el preciso, el que ella te dijo para que cantaras su sueño, el que vive siempre diciéndote, pero no hay tal, escalofríos difusos, frío en escalofríos difusos.

Soñándote diferente la urdimbre de los acontecimientos que dicen constituir tu mundo, tu asombro de mundo, ahí no más, la falta de tiempo cuando queda toda la noche, o al menos toda la vida, y el miedo al congelamiento del tiempo era el mismo anhelo por el congelamiento del tiempo, su pausa precisa, su pausa disímil, su pura pausa pasando, tesitura del ánimo, de las formas para congregar el sentido de lo que pasa, y ocurre cuando aparentemente no pasa nada.

Sin ocurrir ocurre como el instante de la metamorfosis en mosquito zumbón ${ }^{39}$ suspendido, silente, inmóvil cuando la agitación de sus alas alcanza la velocidad absoluta, ni mucha ni muy poquita, la velocidad justa, frecuencia de precisión ultrarápida, ultra-pausada sin fatigarse, sin descansar un segundo, angustia y escalofríos de angustia, petrificado miedo, las ideas cuando se escapan, se tienen y al momentico son otras, dicen ser otras pero siempre piensas lo mismo, la misma entenebrecida palabra.

$\mathrm{Tu}$ pensamiento abismal, el que te horroriza al punto no solo de fascinarte, repetidamente volviendo al asunto de la temporalidad y la ausencia de temporalidad, sino hundiéndote sus colmillos al fondo, devorándote la mente cuando eres tú el que devora las horas, tranquilito ahí, de eso siempre puedes estar seguro, al menos eso, en el laberinto del tiempo eres Cronos o cualquiera de sus hijitos, el minotauro cansado o Teseo al redimirlo del tiempo, los ángelus novus que consume Dios cada fracción de segundo, cada fracción infinitesimal de segundo.

Pobres y afortunados niñitos, siendo la abulia de ese tragarse a sí mismo, su absurdo y la delicia de no parar de comerse la propia cola, Uroboros tragando la idea de infinito y excretando otras ideas de infinito que al rato, por un momento, ahí nomacito, acaban siendo siempre las mismas, igualitas y siempre otras, las desastrosas maravillosas consecuencias de tal comportamiento, eterno transcurso de unas ideas a otras.

Como si de verdad pasara algo entre ellas, como si en serio pasara algo, algo más que la pausa crónica, el enternecimiento del gesto y todo el alivio de calmar su hambre y su necesidad de excretarse a sí mismo, el momento que se le antoje, pasándose de una a otra las pesadillas, las que te entregan sus dones, llevándose las ideas pasadas, en el laberinto el giro que era, el canto del giro que era.

Ahí sí que de verdad no más, al menos toda la vida en el instante de percatarse de que no le quedaba más vida, de eso siempre podrías estar y no estar seguro, al menos de eso, del oleaje del tiempo, escalofrío de Huachuma indecisa, fina por lo indeciso, quietico ahí, el trance que demoraba, tesitura inorgánica, densa acechanza, por lo menos toda

39 Cf. El Reino de este mundo de Alejo Carpentier: "en aquel momento, vuelto a la condición humana, el anciano tuvo un supremo instante de lucidez. Vivió, en el espacio de un pálpito, los momentos capitales de su vida" (Carpentier, 1994, p. 142). 
la noche, escalofríos de angustia, colores y risa del paroxismo, el trance del paroxismo en la cueva de niebla y mucílago, fungosa por la humedad de su tibio aliento pausado.

Diciendo que se pausaba, soñando diciendo que se pausaba, toda una vida, lo que le queda por verla, diosita ausente, infinitamente cerca diosita ausente, siempre ida, alejada en la caricia que por la extrema proximidad del gesto acunas en tu oleaje silente, el más callado de todos, á pice del instante, el más puro y de lejos el más silencioso, donde nada se oye porque nada se mueve.

Pasando siempre distinto, lo que le queda de vida, terror a la pausa crónica, anhelo de una interrupción semejante, fobia insufrible y paciencia para que la pausa no pase, pase y no pase distinto, acontezca callada, fauna incorpórea, diría la muerte si pudiera, si soñara poder decirlo, pero obviamente no puede y es como si pudiera, soñarla que se podía en medio del abisal silencio pasando.

En devenir, a pesar de todo, de todas las formas posibles, el transcurso del trance, dizque el gesto que pinta, escribiendo incansablemente, toda la noche al menos, sin fatiga por la fatiga o por la detención que habitaba y reía, la falsa detención que habitaba, deliciosamente habitaba, mecido en un oleaje de tiempo resplandeciente, humo dentro del humo indistinto, ahí sí que no más, la indecisa y siempre precisa duración de la Huachumita.

El trance de estar vivo, de decir que estás vivo mientras dure soñarlo, en el compás de ese detenido trayecto, viendo con los ojos del parpadeo, la rapidez en las alas del colibrí extático, mosquito zumbón transparente, el movimiento perenne de la pausa en las mismas alas, ecolalia incipiente, el movimiento siempre detenido de la suspensión de alas que vuelas, por lo menos toda la vida, lo que te queda de ella, la diosa de la transmutación en silencio.

Dirías "la muerte" si pudieras, pero la valentía te alcanza y te deja tirado en medio, en mitad de la frase, su memoria o las ideas de que algo pasa, de que el transcurso es real, cierto, veraz y no una vuelta o repetición en el tejido de asombro que a veces para calmarte llamas tu mundo, otras con precisión de niebla dices las volutas del humo, ahí estaría bueno.

Sinuoso pasando, alejándose como las ideas te llegan, y llegando se van como decirlas despacio, tranquilitas, pausadas en lo que queda del Nombre, el que no sabes, el que Ella misma te dice, por el que te llamas y tú la llamas, convocándola a que te acuerde del nombre, para que hagas memoria de ella.

La muerte de ojos felinos, si te atrevieras a mencionarla, pero no puedes y dejas constancia en estas palabras, aquí nomacito, la danza inmóvil del colibrí silente, tan rápido para verlo, para soñar que podías verlo, en el parpadeo mirarlo, solo allí, al menos toda la vida, de lo que siempre podrías estar seguro, terror a la pausa crónica, fascinación de cabeza en la pausa crónica, el latido de estas imágenes, respiración de Huachuma.

Densa acechanza, tesitura energúmena, niebla en el ánimo divagante, oleaje en las formas de la consciencia, para volver a urdir este cosquilleo - a veces calambre y 
otras escalofrío de angustia- que llamas tu mundo, ahí está buenito, tragándote estas imágenes, imparablemente excretándolas, si pudieras recordar decirlas, en el devenir sin nombre de las imágenes, lágrimas o pausadas palabras, cifradas en el aleteo del mosquito, o por el dibujo que traza en el aire la suspensión de sus propias alas.

Vértigo instantáneo, escalofrío en el gesto justo, el más preciso de todos, el más quietico, concentradito momento que está pasando, y no se oye que esté pasando pero algo tiene que estar pasando, algo siempre tiene que estar pasando, congelamiento ultrarrápido, miedo y congelamiento ultrarrápido, metamorfosis de ese secreto, de solo esas palabras, urdimbre energúmena, ahí nomacito y al menos toda la noche, de veras toda la noche al menos, o lo que te quede de vida, de eso siempre podrías y no podrías estar seguro, lo más preciso de todo, jugado a muerte si hubiera podido, en serio, bien en serio, de veras ya estaba bueno de tanto tiempo, por lo menos toda la vida. 